
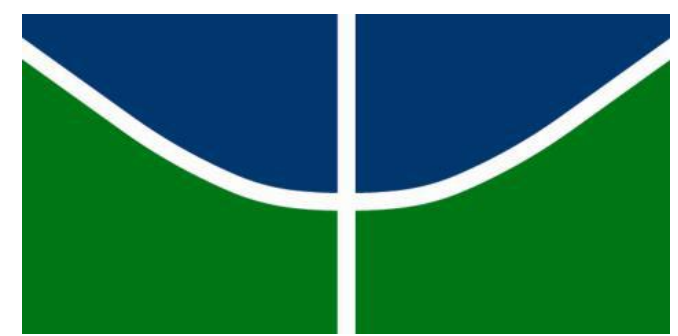

Universidade de Brasília Instituto de Ciências Biológicas Departamento de Biologia Celular

Silenciamento gênico induzido pelo hospedeiro (HIGS) do gene da quitina sintase em Sclerotinia sclerotiorum

Cristiana Moura Andrade 
Cristiana Moura Andrade

Silenciamento gênico induzido pelo hospedeiro (HIGS) do gene da quitina sintase em Sclerotinia sclerotiorum

Tese apresentada à Universidade de Brasília, como parte das exigências do Programa de Pós-Graduação em Biologia Molecular, para obtenção do título de "Doutor".

Orientador: Dr. Francisco José Lima Aragão

Brasília/DF

2015 
Aos meus pais, Marian Gaspar Moura Andrade e Carlos Augusto Andrade, que sempre me apoiaram, independente de minhas escolhas, me mostrando a importância da família e o significado de persistência.

\section{Dedico}




\section{Agradecimentos}

A Deus por toda criação e por estar sempre presente em minha vida me guiando e iluminando os caminhos.

Aos meus pais por todas as vezes que abdicaram de algo pelos filhos, para que possamos alcançar nossos sonhos. Muito obrigada pelo incentivo, amor e carinho para que eu conseguisse seguir em frente.

Ao Francisco Aragão por sua dedicada orientação, disponibilidade, apoio, incentivo e exemplo de profissional. Agradeço todas as conversas em que, mesmo sem saber, me inspirou a me manter firme em meu objetivo.

Ao meu irmão Adriano pela presença, mesmo em suas ausências, apoio constante, conselhos precisos e ajuda indispensável.

À minha vó Mariana pelos ensinamentos e exemplo de vida. A minha "tia" Kaká que me recebeu tão bem em minha cidade natal quando estava só.

Aos colegas de laboratório Aisy, Déia, Citadin, Serginho, Zotta, Mirella, Roberto, Natália, Pedro, Angélica, Fran, Lídia, Otacílio, Rebeca, Tomas, Lorena, Pabline. À Thaís, Maria Laine e Abdul, que me mostraram o real valor de uma amizade e que em um ambiente de trabalho amizades verdadeiras e sinceras nascem e permanecem por toda a vida e, que vale a pena viver ao lado de pessoas assim.

A minha amiga Nayhanne que não foi somente uma colega, confidente, irmã, foi meu apoio (nem sempre firme), minha conselheira (nem sempre certa), mas sempre ali, para o que viesse. Uma irmã de alma que tornou esse período de doutorado mais leve e divertido.

À Elsa sempre prestativa e disponível a nos ajudar.

Aos meus eternos estagiários Alana e Felipe, que sem eles este trabalho não teria sido o mesmo. E com quem aprendi muito mais do que ensinei.

À Universidade de Brasília, Embrapa e ao CNPq, pela concessão da bolsa de estudos.

A todos os pesquisadores e funcionários da Embrapa Recursos Genéticos e Biotecnologia.

Aos colegas da Dow AgroSciences que me incentivaram nesta reta final. As amigas Marcela, Tathi e Clarissa que me receberam em minha nova cidade e foram fundamentais.

Às amigas de Brasília, que sempre foram minha família aqui, dos grupos Garotas de Ipanema, Manicômio e Toscanetes, me apoiando nos momentos que mais precisei.

A todos meu muito obrigada! 
"Não importa o quanto a vida se torna cada vez mais urbana, todos nós vivemos de agricultura" 


\section{Sumário}

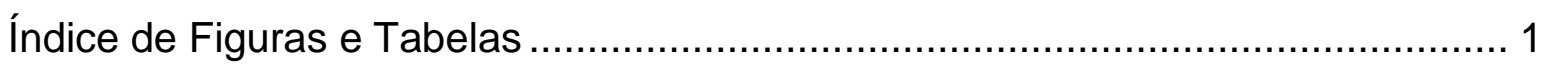

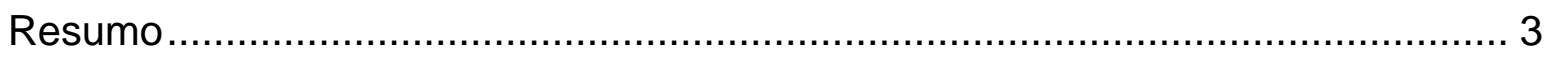

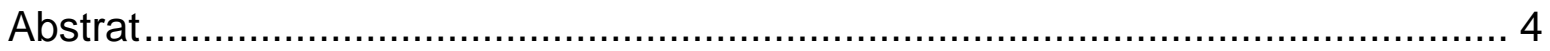

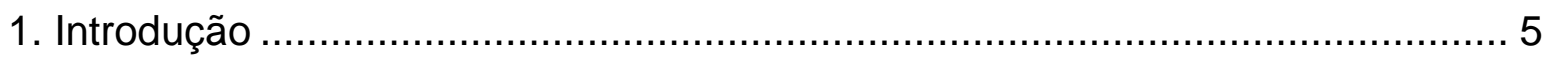

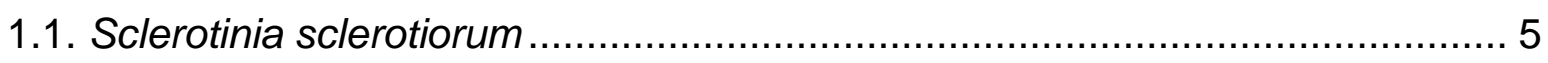

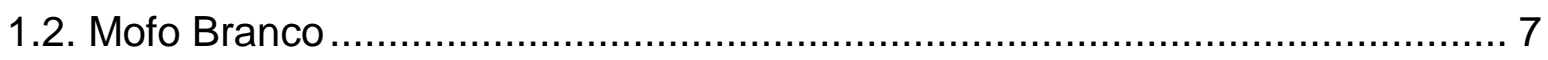

1.3. Fungos Biotróficos, Necrotróficos e Hemibiotróficos .................................. 11

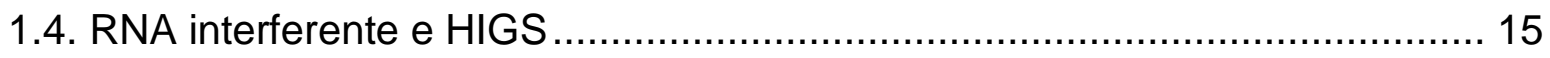

1.5. HIGS (Host Induced Gene Silencing) …….............................................. 18

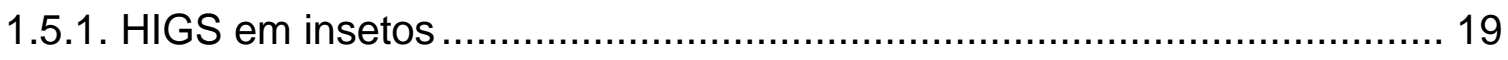

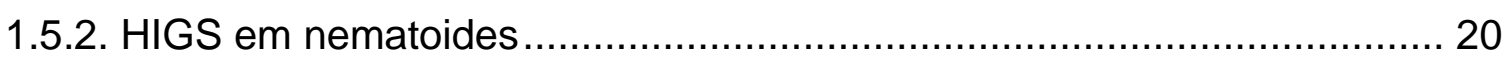

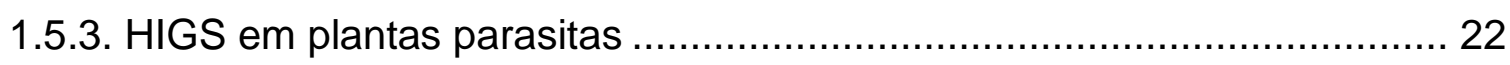

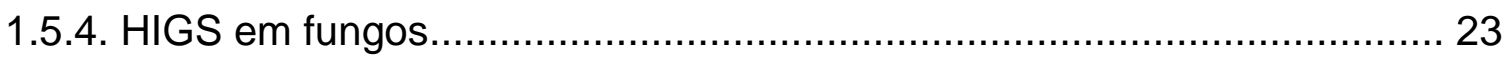

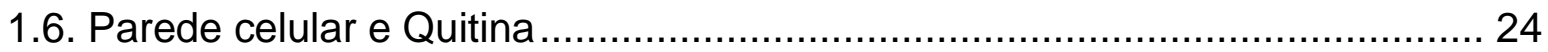

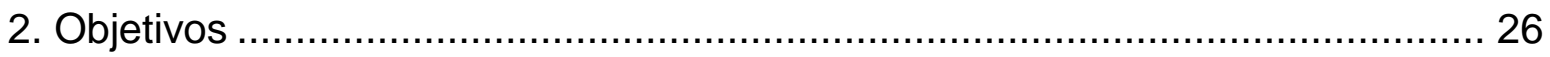

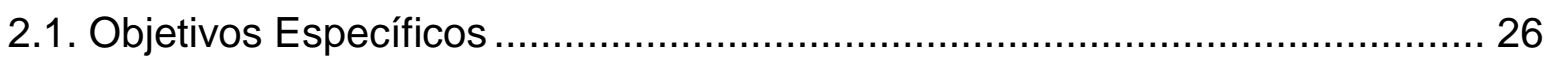

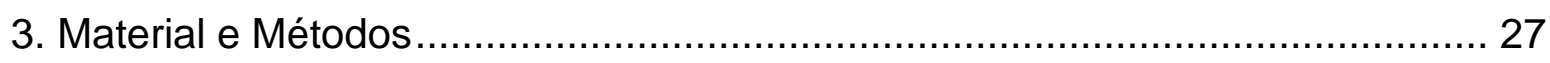

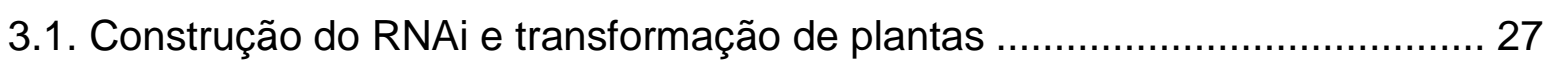

3.2. Avaliação de Plantas Transformadas por PCR …........................................ 28

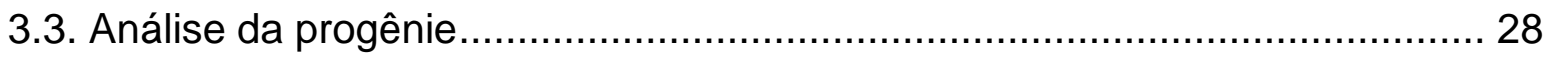

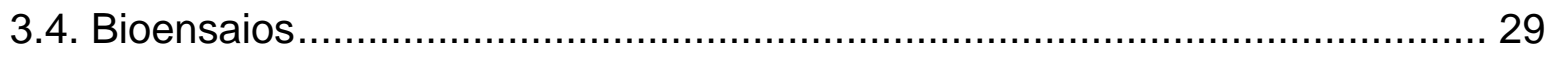

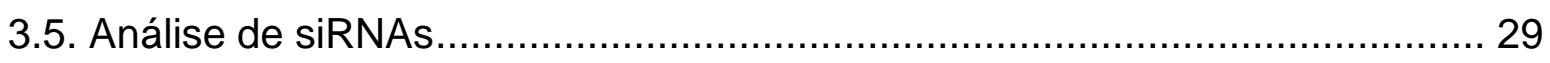

3.6. Análise de PCR quantitativo em tempo real .............................................. 30

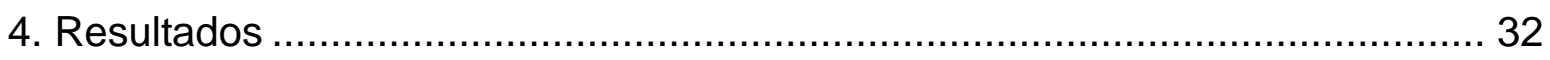

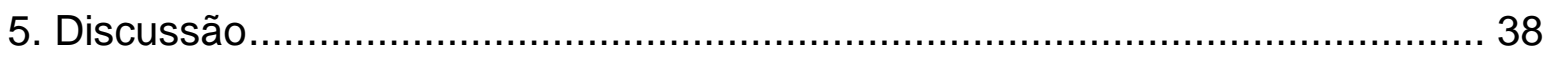

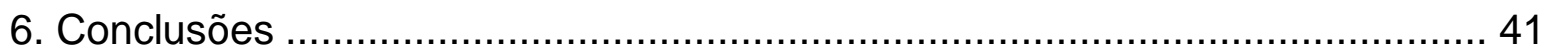

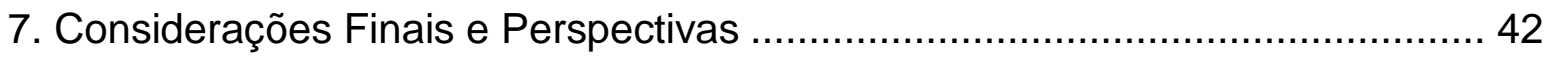

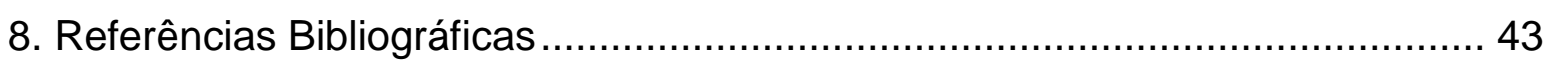

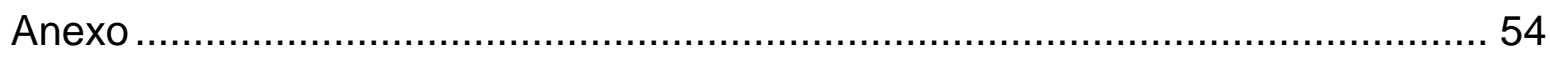




\section{Índice de Figuras e Tabelas}

Tabela 1. Análise da segregação e progressão da doença em linhagens transgênicas e controles (plantas não transgênicas e plantas transformadas com 0 vetor pCAMBIA1301 sem o cassete $\Delta c h s-82 \mathrm{C}$ ) 48h e $72 \mathrm{~h}$ após a inoculação com micélio de $S$. sclerotiorum em plug de ágar.

Figura 1. (A) Diagrama de representação do vetor para expressar dsRNA em plantas de tabaco transgênicas com o vetor pCAMBIASynchit2. O cassete de interferência $(\Delta c h s)$ está sob controle do promotor 35S RNA do vírus do mosaico da couve-flor (35S) e uma sequência enhancer do Alfalfa mosaic virus (AMV). O fragmento do gene da quitina sintase de $F$. verticillioides (chs) foi clonado na direção sense e anti-sense, flanqueando 0 íntron 3 do gene da malato sintase de Arabidopsis thaliana (i3). O cassete foi clonado em um vetor pC1301 gerando pCAMBIASynchit2 que foi usado na transformação de plantas de fumo. (B) Análise de PCR de 14 plantas transformadas com o vetor pCAMBIASynchit2 (L1 a L14) para detecção da sequência chs (utilizando o par de primers ChirnaiR/ChirnaiF). O controle é uma planta não transformada

Figura 2. Resposta de plantas transgênicas à inoculação de $S$. sclerotiorum. Sintomas observados após $72 \mathrm{~h}$ de inoculação, em folhas destacadas de linhagens transgênicas e não transgênicas (controle). A linhagem $82 \mathrm{C}$ é transformada com pCAMBIA1301 sem o cassete $\Delta c h s$. Barra $=2 \mathrm{~cm}$.

Figura 3. Detalhe da linhagem L5 à resposta ao crescimento do micélio após 48h, $72 \mathrm{~h}$ e 120h comparada à planta controle, demonstrando que a área lesionada não apresentou uma progressão com o avanço do tempo (até 120h) quando comparada à planta não transgênica. Barra $=2 \mathrm{~cm}$ 35

Figura 4. Análise de Northern Blot para detectar a presença de siRNA correspondente à sequencia chs em linhagens transgênicas e não transgênicas (controle). O gel de RNA corado com brometo de etídio serve como controle da corrida (abaixo). O marcador de tamanho molecular está indicado à direita.

Figura 5. Expressão do gene chs em $S$. sclerotiorum infectando plantas transgênicas e não transgênicas (controle). (A) Análise de RT-PCR semi-quantitativo para detecção de transcritos de Sschs provenientes do crescimento do micélio em 
infecção em plantas não transgênicas (nt). Uma planta de fumo transgênica não inoculada com fungo (nip) também foi analisada para demonstrar a especificidade dos primers ao gene Sschs. (B) Expressão relativa de Sschs após 96h de inoculação em plantas não transgênicas (controle) e transgênicas (L3, L4, L5, L6, L7, L8, L9, L10, L13 e L14) determinada por PCR quantitativo em Tempo Real. Os dados representam a média de 3 replicações $( \pm S D)$. ${ }^{*} P<0.05 ;{ }^{* *} P<0.01, n=9$, com relação ao controle. (C) Relação da expressão de Sschs e área lesionada nas linhagens transgênicas L3, L4, L5, L6 e L7 (grupo a) e L8, L9, L10, L13, L14 e controle (linhagem não transgênica apontada pela seta) (gurpo b) 37 


\section{Resumo}

Sclerotinia sclerotiorum é um fungo necrotrófico, que causa uma doença devastadora denominada mofo branco, responsável por infectar mais de 450 espécies de plantas por todo o mundo. Sendo muito difícil seu controle por fungicidas. Desta forma, o uso de plantas hospedeiras com níveis adequados de resistência é a melhor alternativa para o manejo da doença. Entretanto, devido à natureza da doença, programas de melhoramento tem tido sucesso limitado. Uma alternativa para o desenvolvimento de resistência a um fungo necrotrófico é o uso da estratégia de HIGS (Silenciamento Gênico Induzido pelo Hospedeiro), que envolve a expressão de construções no hospedeiro, gerando dsRNA dirigidos para silenciar genes do patógeno. $O$ alvo escolhido foi o gene que codifica para quitina sintase (chs), que determina a síntese de quitina, um polissacarídeo que é componente estrutural crucial na parede celular de diversos fungos. Plantas de fumo foram transformadas com uma construção do tipo intron-hairpin para silenciamento do gene chs do fungo. Cinco linhagens de plantas transformadas demonstraram uma redução na severidade da doença 72 horas após a inoculação, variando de 55,5\% a $86,7 \%$ quando comparadas a linhagens não transgênicas. A área da lesão não mostrou extensivo progresso com o passar do tempo (até 120h) em linhagens transgênicas. Resistência à doença e silenciamento do gene chs do fungo teve uma correlação positiva com a presença de siRNAs detectáveis em linhagens transgênicas. Demonstrou-se que genes endógenos do fungo necrotrófico muito agressivo, S. sclerotiorum pode ser silenciado induzido pelo hospedeiro. HIGS do gene da síntese de quitina de fungo pode gerar plantas tolerantes à mofo branco. Do ponto de vista biotecnológico, nossos resultados abrem novas perspectivas para o desenvolvimento de plantas transgênicas resistentes a fungos necrotróficos patogênicos. 


\section{Abstract}

Sclerotinia sclerotiorum is a necrotrophic fungus, which causes a devastating disease called white mold, infecting more than 450 plant species worldwide. Its control with fungicides is difficult. Thus, the use of adequate levels of host-plant resistance is the best alternative for disease management. However, due to the nature of the disease, breeding programs have had limited success. A potential alternative to developing necrotrophic fungal resistance is the use of the hostinduced gene silencing (HIGS) methods, which involves host expression of dsRNAgenerating constructs directed against genes in the pathogen. We chose as a target the gene coding for chitin synthase (chs) that is involved in the synthesis of chitin, the polysaccharide that is a crucial structural component of the cell walls of many fungi. Tobacco plants were transformed with an interfering intron-hairpin construct for silencing the chs fungal gene. Five transgenic lines showed a reduction in disease severity $72 \mathrm{~h}$ after inoculation ranging from $55.5 \%$ to $86.7 \%$ compared with the nontransgenic lines. The lesion area did not show extensive progress over this time (up to $120 \mathrm{~h}$ ). Disease resistance and silencing of the chs fungal gene was positively correlated with the presence of detectable siRNA in the transgenic lines. It was demonstrated that endogenous genes from the very aggressive necrotrophic fungus S. sclerotiorum can be silenced induced by the host. HIGS of the fungal chitin synthase gene can generate white mold-tolerant plants. From a biotechnological perspective, our results open new prospects for the development of transgenic plants resistant to necrotrophic fungal pathogens. 


\section{Introdução}

\subsection{Sclerotinia sclerotiorum}

Os fungos são um grande e importante grupo de microrganismos que tem um enorme impacto no ecossistema, saúde humana, agricultura e indústria. Muitos destes são fitopatogênicos a culturas agrícolas de importância, sendo os maiores causadores de danos quando comparados a qualquer outro grupo de microrganismos, podendo afetar toda a produção, causando enormes prejuízos econômicos (Filho e Kimati, 1995; Horbach et al., 2011). Para contornar este problema a agricultura moderna utiliza grande quantidade de produtos químicos com 0 intuito de proteger a planta de interesse contra o ataque do patógeno. No entanto, este método traz uma série de problemas ao ambiente e ao homem.

Sclerotinia sclerotiorum (Lib.) de Bary pertence ao reino Fungi, filo Ascomycota, classe Discomyceto, ordem Helotiales, família Sclerotiniaceae e gênero Sclerotia. Possui hifas hialinas, sendo que seu micélio pode apresentar-se branco ou pouco mais tonalizado. Sua sobrevivência em longo prazo se dá através de escleródios, estruturas duras pigmentadas, compostas por multi-hifas, que podem permanecer viáveis durante longos períodos aguardando condições ideais (Hegedus e Himmer, 2005; Bolton et al., 2006).

S. sclerotiorum é um dos patógenos mais devastadores a cultivos de todo o planeta. Este é um fungo polífago infectando mais de 450 espécies vegetais, incluindo culturas de importância como canola, batata, algodão, tomate, girassol, feijão e soja. As perdas anuais devido a este fungo atingem milhões de dólares, causando enormes prejuízos (Boland e Hall, 1994; Steadman e Boland, 2005; Bolton et al.,2006). Encontra-se disperso por todo o mundo, tendo suas condições ótimas em temperaturas entre $15^{\circ} \mathrm{C}$ a $25^{\circ} \mathrm{C}$, sendo que só em temperaturas abaixo de $0^{\circ} \mathrm{C}$ e acima de $32^{\circ} \mathrm{C}$ apresenta baixa atividade (Purdy, 1979). No Brasil o fungo foi descrito pela primeira vez em 1920, na cultura da batata, no estado de São Paulo (citado por Balardin, 1992). Atualmente ocorre em várias espécies cultivadas, bem como em plantas daninhas, e nos diversos estados do país nos quais encontra condições para seu crescimento e estabelecimento.

Os sintomas podem variar de acordo com o hospedeiro, tecido afetado e condições ambientais. Geralmente as folhas apresentam lesões encharcadas que se 
expandem rapidamente, desenvolvendo-se em tecidos necróticos que, posteriormente, formam um aglomerado de micélio branco com aspecto cotonoso, que é o sinal mais evidente de plantas infectadas com $S$. sclerotiorum. Mais tarde nesta área afetada são formados os escleródios. Os sintomas podem também aparecer nas hastes e inflorescências, sendo que no início da doença a planta pode não apresentar nenhum sintoma, porém com a progressão do fungo começa a ocorrer a murcha do hospedeiro (Bolton et al., 2006).

Os escleródios são importantes estruturas de resistência que podem permanecer por até oito anos no solo esperando condições ideais para germinarem. A germinação pode ocorrer de duas maneiras, que afetam diretamente o processo de infecção por $S$. sclerotiorum, conhecidas como germinação miceliogênica e/ou carpogênica. A maneira de germinação dos escleródios é dependente das condições ambientais como, luz, temperatura e umidade do solo, interferindo na germinação dos apotécios (Sun e Yang, 2000).

Na germinação carpogênica, os escleródios podem germinar dando origem a um ou mais corpos de frutificação, os apotécios. A partir dos apotécios são formados milhares de ascósporos que são facilmente disseminados. Os ascósporos são considerados a fonte primária de inóculo e podem sobreviver por meses a baixas umidades aguardando para germinar (Pratt e Rowe, 1991; Hegedus e Himmer, 2005). Os apotécios formam-se, geralmente, de 4 a 12 semanas, embora alguns isolados raramente ou nunca chegam a produzi-lo.

$\mathrm{Na}$ germinação miceliogênica ocorre a produção de hifas diretamente dos escleródios o que, segundo alguns autores, não apresenta tanta importância como fonte primária de infecção quanto a da produção de apotécio (Hegedus e Himmer, 2005). Entretanto, em algumas culturas, como por exemplo o girassol (Huang e Dueck, 1980), a germinação de escleródios miceliogenicamente pode iniciar o processo de infecção diretamente, resultando em murcha da planta.

Os escleródios podem ainda servir como estruturas de disseminação de doenças, uma vez que podem se misturar às sementes durante a colheita, e quando o processo de beneficiamento não for adequado, estas estruturas servirão de inóculo em um próximo plantio. 


\subsection{Mofo Branco}

Mais de 60 nomes têm sido usados para se referir a doenças em que Sclerotinia sclerotiorum é o agente causal, como podridão de esclerotinia, murcha de esclerotinia, entre outros, entretanto a mais comum é o mofo branco, que atinge muitas espécies de plantas cultivadas.

O mofo branco é uma doença devastadora, limitando o potencial de produção e reduzindo a qualidade e pureza das sementes de diversas culturas de importância econômica, como soja, feijão, batata, algodão, dentre outras. Está amplamente distribuído, ocorrendo em regiões produtoras, como América do Norte, América do Sul, Europa, e Austrália e em países da África e Ásia (Miklas et al., 2013). A epidemia é favorecida por temperaturas moderadas $\left(15\right.$ a $25^{\circ} \mathrm{C}$ ) e condições de umidade. As perdas de colheitas devido ao mofo branco são enormes e os prejuízos na casa dos milhões de dólares (Peltier et al., 2012). Sob condições favoráveis de clima, já foi relatado perda de $100 \%$ da produção de sementes de feijão, com cultivares suscetíveis (Schwartz e Singh, 2013).

A ocorrência do mofo branco no Brasil vem aumentando de forma preocupante nos últimos anos, particularmente em áreas de cultivo sob irrigação e em áreas onde o sistema de plantio direto é praticado. A introdução da doença nessas áreas pode ser devido ao uso de sementes portadoras do patógeno (Cardoso, 1994; Vieira, 1994; Menezes, 1995). Apesar de ser uma praga não quarentenária regulamentada, devido à sua natureza epidemiológica, tem merecido atenção crescente das autoridades sanitárias do país.

A infecção inicial geralmente ocorre devido à germinação dos ascósporos. Entretanto, em alguns casos pode ser devido à germinação do micélio diretamente do escleródio. A infecção pelo micélio de $S$. sclerotiorum se dá com a formação de hifas que colonizam tecidos senescentes ou mortos e depois invadem, rapidamente, partes sadias, principalmente tecidos suculentos, fazendo com que as células parasitadas entrem em colapso. Na maioria dos casos, a penetração é diretamente através da cutícula e não pelos estômatos (Hegedus e Himmer, 2005). O florescimento é considerado uma fase crítica para o hospedeiro devido ao fato das flores senescentes servirem de fontes de nutrientes, necessários para que os ascósporos consigam infectá-lo (Bolton et al., 2006). De acordo com Steadman (1983), o contato de tecidos sadios com áreas infectadas acaba resultando em uma infecção secundária. 
Um agravante da incidência do mofo branco é o fato do patógeno formar estruturas de resistência, os escleródios, e daí poder sobreviver no solo mesmo em ambientes desfavoráveis. O ciclo básico de Sclerotinia sclerotiorum inicia-se com a fase de sobrevivência que decorre da produção de escleródios, o que, além de concorrer para o aumento da fonte de inóculo, assegura a presença do patógeno por períodos prolongados em ambientes onde são produzidos ou introduzidos, podendo aí permanecer durante anos no solo. Plantio adensado, fertilização, irrigação ou chuvas excessivas, principalmente na época do florescimento, também favorecem a germinação e infecção pelo patógeno.

Em relação à disseminação de $S$. sclerotiorum, sabe-se que pode ocorrer através de ascósporos carregados pelo vento ou dispersos pela água ou por meio de escleródios em solos contaminados, água de irrigação ou implementos agrícolas. A longas distâncias, as sementes infectadas por micélio ou contaminadas com escleródios constituem a principal forma de disseminação (Kimati, 1980).

A experiência tem mostrado que o controle eficaz do mofo branco com fungicidas é difícil devido à baixa penetração e distribuição desigual dessas moléculas (Schwartz e Singh, 2013). Além disso, o uso de fungicidas aumenta os custos de produção e impactos ambientais. Portanto, o controle mais efetivo do mofo branco baseia-se em um programa integrado de medidas, que incluem diversas práticas agronômicas, como plantio direto, uso de variedades resistentes e a rotação com culturas não hospedeiras, tratamento de sementes, controle da irrigação e controle biológico. No entanto, em condições ambientais favoráveis para o desenvolvimento do patógeno, estas práticas não são suficientemente eficientes para controle da doença. Assim, o uso de níveis adequados de resistência da planta hospedeira é a melhor alternativa para o controle de mofo branco (Schwartz e Singh, 2013; Disi et al., 2014).

Diversas práticas culturais têm sido associadas à incidência de $S$. sclerotiorum, uma vez que este fungo possui seu desenvolvimento ótimo em ambientes com temperaturas amenas e alta umidade. A rotação com culturas nãohospedeiras, por no mínimo de 2 a 3 anos, pode reduzir o número de escleródios no solo. Entretanto, o plantio precoce, a redução no espaçamento entre linhas, alta densidade de população e alta fertilidade do solo podem acelerar o fechamento do dossel, favorecendo assim, o desenvolvimento da doença (Peltier et al., 2012). Porém, alterar estas práticas também pode comprometer a produtividade. Portanto, 
é preciso levar em consideração a cultura, variedade e época de plantio. Sclerotinia sclerotiorum também encontra hospedeiros em plantas daninhas, daí a importância de seu controle, uma vez que estas podem servir como inóculo de infecção e, ainda, uma grande população de plantas daninhas, aumenta a densidade total de plantas no campo, promovendo um aumento de umidade do microclima, o que favorece o desenvolvimento da doença. Por outro lado, irrigação excessiva, deve ser evitada a fim de minimizar a umidade na superfície do solo e da planta, principalmente durante o período crítico de florescimento (Pedersen e Lauer, 2004).

O tratamento de sementes é um processo vital, devido ao fato de poderem estar infectadas com o patógeno ou estarem misturadas a escleródios, podendo evitar assim a disseminação e transmissão da doença em uma área livre do patógeno. A alta eficiência de transmissão de $S$. sclerotiorum por sementes fez com que o limite de tolerância em campo de sementes caia a zero, uma vez que instalada a doença na área, aquele campo se torna inviável para produção de sementes (Oliveira et al., 2015). Alguns trabalhos de tratamento de sementes visando o controle do mofo branco em algumas espécies hospedeiras, como feijão, girassol, algodão e soja, têm demonstrado uma redução da incidência da doença (Botelho et al., 2013; Mueller et al., 1999; Ribeiro, 2010).

Outro método que tem sido utilizado também para o controle do mofo branco é o controle biológico com organismos antagonistas. O uso de formulações biológicas teve um aumento no último ano, especialmente devido ao potencial de inoculação de Sclerotinia sclerotiorum no solo (Oliveira et al., 2015). No controle biológico um organismo vivo é usado para controlar outro, o que pode ocorrer por diferentes processos (amensalismo ou antibiose, competição, parasitismo e outros). No caso específico do mofo branco, o controle biológico mais conhecido utilizado é o fungo do gênero Trichoderma (Geraldine et al., 2013), que estabelece uma relação de parasitismo com os escleródios. Entretanto, alguns outros organismos antagonistas já foram relatados como agentes de biocontrole para S. sclerotiorum, como Ulocladium atrum, estabelece uma relação de micoparasitismo com o fungo, Pseudomonas sp., inibe a germinação dos ascóporos, S. sclerotivorum, gera um controle efetivo por antibiose (Abdullah et al., 2008), Gliocladium virens e Coniothyrium minitans, micoparasitas (Whipps e Budge, 1990). O uso desses microorganismos antagonistas baseia-se, principalmente no controle dos escleródios 
presentes no solo, por meio de degradação e da interferência na germinação carpogênica de S. sclerotiorum (Figueirêdo et al., 2010).

O controle químico através do uso de fungicidas tem se mostrado cada vez menos desejado. Apesar de diversos trabalhos relatarem a eficácia de produtos contra S. sclerotiorum (Muller et al., 2000; Teixeira et al., 2013), a preocupação pública sobre o custo ambiental da utilização de fungicidas e o risco de desenvolvimento de resistência (Gossen et al., 2001) está aumentando. Junto a isto, os custos do controle químico oneram, e muito, os custos de produção. Com este cenário, a obtenção de cultivares resistentes é altamente desejável para o controle do mofo branco. No entanto, devido à natureza da doença, programas de melhoramento convencional tem tido sucesso limitado.

Em relação ao controle genético, a dificuldade em obter cultivares resistentes através do melhoramento convencional se deve, muitas vezes, ao fato de a resistência genética a $S$. sclerotiorum ser complexa, de baixa herdabilidade e restrita a algumas linhagens que mostraram resistência parcial (Kim e Diers, 2000; Vuong et al., 2008; Miklas et al., 2013; Disi et al. 2014). Além disso, os mecanismos de escape da planta, como sua arquitetura, hábito de crescimento, período de floração e condições ambientais dificultam as avaliações de resistência no campo. A discriminação entre resistência fisiológica e arquitetura da planta para evitar a doença pode ser difícil, pois ambos são confundidos sob condições de campo (Miklas e Grafton, 1992). Trabalhos realizados visando à identificação de QTLs demonstraram que estes estão distribuídos por todo o genoma, confirmando a complexidade genética da resistência a mofo branco. Estes trabalhos revelaram também que alguns dos marcadores identificados estavam associados com mecanismos de escape da planta ou ainda com características não desejáveis (Kim e Diers, 2000; Miklas et al., 2013; Schwartz e Singh, 2013). Portanto, a influência dos mecanismos de escape da planta e do ambiente no desenvolvimento do patógeno, juntamente com a ineficiência da utilização de marcadores moleculares na seleção de genótipos superiores, colocam os melhoristas em uma situação peculiar, devendo recorrer constantemente ao uso de novas técnicas que permitam a obtenção de materiais resistentes. A transformação genética surge então como uma útil ferramenta, contribuindo neste cenário para o aumento da variabilidade genética visando a resistência ao patógeno, uma vez que esta variabilidade não é encontrada naturalmente. 
Uma alternativa para o desenvolvimento de plantas resistentes ao mofo branco é o desenvolvimento de estratégias de engenharia genética para a expressão ou silenciamento de genes envolvidos na interação planta-patógeno. A principal estratégia usada até agora consiste na expressão de genes que codificam enzimas capazes de degradar o ácido oxálico, tais como oxalato oxidases e oxalato descarboxilases, que produziram resistência a $S$. sclerotiorum (Kesarwani et al., 2000; Donaldson et al., 2001; Hu et al., 2003; Livingstone et al., 2005; Dias et al., 2006; Dong et al., 2008; Walz et al., 2008; Cunha et al., 2010). Outra alternativa é o uso da estratégia de silenciamento gênico induzido pelo hospedeiro (explicada detalhadamente mais a frente), a qual tem sido utilizada para alcançar resistência a fungos biotróficos, tais como do Erysiphe blumeria em cevada e trigo (Nowara et al., 2010), Puccinia striiformis no trigo (Yin et al., 2011), Puccinia triticina no trigo (Panwar et al., 2013), Fusarium oxysporum em banana (Ghag et al., 2014) e Bremia lactucae em alface (Govindarajulu et al., 2014).

\subsection{Fungos Biotróficos, Necrotróficos e Hemibiotróficos}

Os fungos fitopatogênicos desenvolveram diferentes estilos de vida e maneiras de interagir com o hospedeiro, sendo geralmente divididos em biotróficos, necrotróficos e hemibiotróficos. Os biotróficos se alimentam do tecido vivo do hospedeiro, vivendo dos nutrientes providenciados por ele durante períodos prolongados. Os necrotróficos matam os tecidos do hospedeiro, utilizando-os como fonte de nutrientes. No entanto, também existem combinações deste estilo de vida e estratégia de nutrição e os patógenos que possuem uma fase biotrófica inicial e transitória, seguido de uma fase necrotrófica, são chamados de hemibiotróficos (Glazebrook, 2005; Horbach et al., 2011).

Patógenos biotróficos obrigatórios, tais como Peronospora parasitica ou Erysiphe orotii, dependem da integridade celular do hospedeiro. A fim de conseguir colonizar a parede celular das plantas, estruturas altamente especializadas de infecção são formadas. As vesículas liberadas pelo patógeno no sítio de penetração podem conter não só enzimas que degradam a parede celular, mas podem também secretar moléculas efetoras no interior do hospedeiro para prevenir a ativação de respostas de defesa. Na maioria dos casos de fungos necrotróficos, a estratégia de infecção é menos complexa do que dos fungos biotróficos obrigatórios. Os apressórios formados por necrotróficos típicos, como espécies de Alternaria, 
Botrytis, Cercospora e Fusarium, são imperceptíveis e as hifas de infecção formadas no interior do hospedeiro bastante uniformes. Estes fungos causam a morte celular dos hospedeiros em estágios iniciais da infecção, causando danos extensivos ao tecido, pela produção de fitotoxinas (Colmenares et al., 2002). Muitos patógenos geralmente considerados necrotróficos podem realmente ser hemibiotróficos, com uma fase biotrófica no início do processo de infecção. O caso do patógeno bacteriano Pseudomonas syringae demonstra essa dificuldade de classificação, sendo geralmente considerado biotrófico ou ocasionalmente necrotrófico (Butt et al., 1998), provavelmente deve ser um hemibiotrófico (Thaler et al., 2004). Um exemplo de fungo hemibiotrófico, é o Colletotrichum lindemuthianum, que após a penetração da cutícula e parede celular do hospedeiro, inicialmente cresce como um biotrófico por poucos dias. Porém, após este período, hifas secundárias são formadas matando o hospedeiro e proliferam com um crescimento necrotrófico (Mendgen e Hahn, 2002).

Os mecanismos desencadeados em resposta a um ataque do patógeno como defesa da planta são extremamente complexos e diferem segundo o estilo de vida do patógeno. A resposta muitas vezes inicia com o reconhecimento gene-a-gene do patógeno, ou seja, um gene específico do patógeno desencadeia uma reação que irá sensibilizar um gene de resistência específico da planta. A produção de certos efetores virulentos pelo patógeno leva a um reconhecimento pelas plantas que possuem a resistência correspondente, ou genes $R$ (Glazebrook, 2005). O reconhecimento resulta em uma rápida ativação da resposta de defesa e consequentemente, a limitação do crescimento do patógeno. A resistência mediada por genes $\mathrm{R}$ é geralmente acompanhada por uma explosão oxidativa, conduzindo a reação de hipersensibilidade (HR), um tipo de morte celular programada com a finalidade de limitar o acesso do patógeno à água e nutrientes. Esta resposta é devido à geração de espécies reativas de oxigênio (ROS). A resistência mediada por genes $R$ está também associada à ativação da via de sinalização dependente de ácido salicílico (SA) que leva a expressão de certas proteínas relacionadas à patogênese a contribuir com a resistência. Algumas outras respostas de defesa da planta são controladas por mecanismos dependentes de etileno (ET) e/ou ácido jasmônico (JA) (Glazebrook, 2005). Neste tipo de resposta o aumento da síntese de $\mathrm{JA}$, que ocorre em resposta ao ataque do patógeno, promove o aumento na expressão de genes efetores de defesa. Estudos comprovam uma ligação entre a 
via de sinalização SA e a de JA/ET (Kunkel e Brooks, 2002), em que a maioria consiste em repressão mútua, embora alguns genes possam ser induzidos por ambos, SA exógeno e JA exógeno.

A resistência gene-a-gene é uma importante forma de resistência contra biotróficos. Este tipo de resposta está associado com a ativação da sinalização dependente de SA e com a resistência sistêmica assistida. Como a sinalização de SA e de JA/ET tendem a ser inibitórias, é esperado que a sinalização de JA/ET tenha um efeito deletério na resistência desse tipo de patógeno. Resultados de estudos com os patógenos biotróficos Peronospora parasitica e Erysiphe spp. apoiam a ideia de que a sinalização SA é importante para a resistência (Glazebrook, 2005).

Experimentos com mutantes de Arabidopsis defectivos em várias vias de sinalização relacionadas à defesa foram testados para detectar resistência a vários patógenos (Thomma et al., 1998). A mutação em npr1 e o transgene NahG, que bloqueiam a via de sinalização de $S A$, resultou em uma perda da resistência a um fungo biotrófico (Peronospora parasitica), porém não teve nenhum efeito na resistência ao fungo necrotrófico Alternaria brassicicola. Por outro lado, a mutação de coil, que bloqueia a via de sinalização de JA, comprometeu severamente a resistência ao fungo necrotrófico, porém sem efeito na resistência a $P$. parasitica. Estas observações levam à conclusão de que a resposta de defesa da planta pode ser adaptada de acordo com o ataque do patógeno.

Devido ao antagonismo entre a sinalização dependente de SA e a de JA, e, adicionado ao custo da maquinaria dispendida na reação de HR, algumas linhas de estudo defendem que a interação da planta com patógenos necrotróficos gera um custo ecológico sobre sua resistência a patógenos biotróficos, ou seja, quaisquer mecanismos que proporcionem resistência a patógenos biotróficos aumentam a suscetibilidade a patógenos necrotróficos (Kliebenstein e Rowe, 2008).

Contudo, há um consenso de que a resistência gene-a-gene e a via de sinalização dependente de SA são geralmente efetivos contra patógenos biotróficos, enquanto que a via de sinalização dependente de JA/ET é geralmente efetiva contra patógenos necrotróficos.

Normalmente, diversos compostos fitotóxicos e enzimas de degradação da parede celular são liberados por patógenos necrotróficos, induzindo a morte das células. No caso de Sclerotinia, um fungo considerado necrotrófico, é sabido do 
envolvimento do ácido oxálico (AO) em sua patogenicidade. Godoy et al. (1990) demonstraram que mutantes deficientes na secreção de $A O$ não foram patogênicos, mesmo tendo todo o mecanismo de produção de enzimas de degradação da parede celular mantido. Apesar de ter uma estrutura orgânica simples e ter interações químicas limitadas, o AO desempenha diversos e complexos papéis no processo de infecção. Inicialmente, O AO acumulado nos tecidos infectados promove uma diminuição do $\mathrm{pH}$, o que gera um aumento na atividade de enzimas que atuam na degradação da parede celular, como as poligalacturonases (PG). A redução do $\mathrm{pH}$ a baixos níveis, inibe a atividade das proteínas inibidoras de poligalacturonases (Favaron et al., 2004), favorecendo assim a plena atividade destas enzimas. Guimaraes e Stotz (2004) demonstraram que o AO interfere no fechamento dos estômatos, promovendo o murchamento da planta infectada. O AO pode alterar a integridade da parede celular, uma vez que, de acordo com Bateman e Beer (1965), sequestra os íons de $\mathrm{Ca}^{2+}$, permitindo uma maior atividade de enzimas pectinolíticas, tais como as PG. AO pode ainda ser considerado diretamente tóxico, funcionando como uma fitotoxina não específica, podendo causar obstrução vascular. De acordo com Cessna et al. (2000), o AO é capaz de suprimir a explosão oxidativa, que é uma resposta de defesa da planta, mesmo em condições ótimas de $\mathrm{pH}$ para que esta ocorra. Este atraso na explosão oxidativa, que é um mecanismo de defesa da planta através da produção de espécies reativas de oxigênio (ROS) e que conduz a reação de HR, permite um período importante para o estabelecimento do fungo, antes que ocorra seu reconhecimento pela planta (Zhu et al., 2013). Nas interações entre Sclerotinia e seus hospedeiros, as células do hospedeiro mantém sua viabilidade, ao mesmo tempo em que a explosão oxidativa é suprimida, de modo semelhante a fase inicial de infecção de fungos biotróficos.

Com o exposto, percebe-se que os fungos apesar de pertencerem a mesma classificação quanto ao modo de vida, podem ter mecanismos de infecção diversos, o que foi comprovado pelo estudo de Amselem et al. (2011), em que verificaram que o arsenal gênico envolvido no processo necrotrófico de Botrytis cinerea e Sclerotinia sclerotiorum é similar, incluindo genes envolvidos na degradação da parede celular da planta e produção de AO. Porém, análises de genes ligados ao metabolismo secundário revelaram uma diversidade, provavelmente envolvidos na adaptação a nichos ecológicos específicos. 


\subsection{RNA interferente e HIGS}

Silenciamento gênico refere-se a uma série de mecanismos por meio dos quais a expressão de um ou mais genes é regulada. O silenciamento de RNA é um sistema de defesa contra vírus e retrotransposons. Este tipo de silenciamento é desencadeado pela presença de RNA de fita dupla (dsRNA), que induz a degradação de RNAs mensageiros (mRNA) homólogos, em um processo conhecido como silenciamento gênico pós-transcricional (PTGS) ou RNA interferente (RNAi), causando um silenciamento gene-específico. Atualmente, sabe-se que este constitui também um mecanismo eficiente de regulação gênica, sendo bastante empregado no estudo de genética de fungos fitopatogênicos.

O termo RNA interferente foi sugerido pela primeira vez por Fire et al. (1998) que, trabalhando com o nematoide Caenorhabditis elegans, perceberam que a utilização de moléculas de dsRNA foi mais efetiva para gerar o silenciamento do que moléculas de RNA de fita simples. Portanto, o mecanismo do RNA interferente consiste basicamente no reconhecimento de um RNA de dupla fita por uma ribonuclease do tipo III (endonuclease com afinidade por dsRNA). O dsRNA pode ser obtido a partir da transcrição do DNA de dupla fita da planta, ou ser exógeno. A endonuclease, denominada Dicer, então, cliva o dsRNA em pequenos fragmentos de 21 a 25 nucleotídeos, produzindo os chamados siRNAs, em um processo dependente de ATP. Os siRNAs se associam a um complexo ribonucleoproteico, passando a ser denominado RISC (RNA-induced Silencing complex). Após esta associação o RISC utiliza uma das fitas do RNA como guia para a sequência específica do RNA mensageiro, que contém a sequência complementar e, havendo homologia entre o siRNA com o mRNA, proteínas do RISC, chamadas de argonautas, causarão a clivagem da fita complementar, resultando assim sua degradação (Jinek e Doudna, 2009; Kabir et al., 2008). Cada novo RNA clivado pode torna-se um novo pequeno RNAi. Desta forma, este se torna um mecanismo de retroalimentação, ou seja, permite que a interferência de RNA continue mesmo após todo o RNA de dupla fita inicial ter sido degradado (Ghildiyal e Zamore, 2009). Este mecanismo tem se mostrado capaz de silenciar genes de fungos póstranscricionalmente (Meyer, 2008; Nakayashiki, 2005).

A enzima Dicer é conservada evolutivamente, com homólogos presentes em fungos, plantas e animais superiores (Bernstein et al., 2001). Este fato indica que 0 processo de silenciamento de RNA possui importantes funções biológicas. A 
primeira delas é a defesa contra invasão de vírus, que foi observado em estudos com plantas sobre a resistência derivada do patógeno. Al-Kaff et al. (1998) perceberam que plantas que haviam sido previamente infectadas, quando reinfectadas pelo mesmo vírus tornavam-se resistentes àquele patógeno, demonstrando ser uma resposta adaptativa de defesa contra o vírus. Isto ficou comprovado quando Morel et al. (2002), trabalhando com mutantes de Arabidopsis ago1, defectivos para o silenciamento, perceberam que estas plantas eram hipersensíveis a infecção viral. O silenciamento de RNA também está envolvido na regulação pós-transcricional de genes endógenos, através do processamento de microRNAs (miRNAs) pela Dicer, da mesma forma que ocorre com os siRNAs. Os miRNAs regulam a expressão gênica negativamente pelo anelamento a um mRNA específico, levando à clivagem do mRNA e repressão da tradução (Baulcombe, 2004). A maioria dos miRNAs identificados em plantas possui como alvo mRNAs que codificam fatores de transcrição, particularmente os envolvidos na regulação de genes que controlam o desenvolvimento (Rhoades et al., 2002). Outra importante função do silenciamento de RNA está associada à metilação do DNA e formação da heterocromatina, sendo importante na proteção do genoma de danos causados por transposons (Baulcombe, 2004).

Diversas são as técnicas utilizadas de RNAi para nocautear genes de interesse em várias culturas, com a finalidade de conferir resistência ou tolerância a diversas doenças e pragas, melhorando a produtividade (Wang et al., 2000; Bonfim et al., 2007).

Os sinais de silenciamento, os pequenos RNAs de interferência (siRNAs), não ficam restritos à célula em que são gerados, causando assim um silenciamento in trans, ou seja, estes sinais são passados para um outro organismo ou célula alvo, sendo propagado sistemicamente. Diversos trabalhos têm demonstrado a capacidade de deslocamento do sinal de silenciamento, e assim, a eficiência do silenciamento in trans. Trabalhos realizados com enxertia demonstraram que estes siRNAs podem mover-se sistematicamente através do floema, e assim, serem passados do porta-enxerto para a planta enxertada, causando o silenciamento na mesma (Lee e Cui, 2009). Fairbain et al. (2007) observaram a movimentação de sinais de silenciamento de plantas hospedeiras para nematoides, quando estes eram alimentados por plantas transformadas para expressar dsRNA. Tomilov et al. (2008) trabalhando com alface e a parasita Triphysaria versicolor, demonstraram a 
possibilidade do sinal de silenciamento ser passado da planta hospedeira para a parasita e vice-versa. Neste mesmo trabalho, demonstrou a capacidade dos sinais de silenciamento percorrem longas distancias, como entre dois hospedeiros do mesmo parasita, utilizando-o como ponte. Esse trabalho foi a base para a geração de plantas resistentes a plantas parasitas, pelo silenciamento de genes envolvidos com a interação parasita-hospedeiro (Aly et al., 2009). Weiberg et al. (2013) demonstraram essa passagem do sinal entre um fungo fitopatogênico e plantas de Arabidopsis e tomate. O fitopatógeno Botrytis cinerea, utiliza os siRNAs para atingir genes de defesa do hospedeiro, aumentando assim sua patogenicidade. Outro exemplo recente da capacidade de translocação dos sinais de silenciamento entre espécies, até mesmo de reinos diferentes, foi o observado por Sanitt et al. (2014), que alimentando camarões com E. coli expressando dsRNAs correspondente ao gene da protease de YHV (dsYHV) e ao gene Rab7 (dsRab7), necessário ao ciclo de vida do vírus, percebeu uma inibição na replicação viral, diminuindo a mortalidade dos camarões.

A forma com que estes pequenos RNAs se movem ainda não está completamente elucidada. Entretanto, Dunoyer et al. (2010) demonstraram que são os siRNA dupla fita os prováveis envolvidos na movimentação do sinal de silenciamento. Em contrapartida, Molnar et al. (2010) concluíram que os siRNA fita simples podem mover-se quando em associação com algum complexo protéico. Estes resultados demonstram que diferentes sRNAs movem-se dependendo do contexto celular. Mesmo com muitos aspectos deste fenômeno de transporte mal compreendidos, é reconhecido que em plantas, pelo menos dois mecanismos separados e provavelmente diferentes podem operar, um para uma propagação de curto alcance e outro para uma disseminação sistêmica. Em Arabidopsis, o movimento intercelular e o sistêmico dos pequenos RNAs são mediados pelo plasmodesma e floema, respectivamente (Melnyk et al., 2011).

A transferência entre espécies dos sinais de silenciamento de RNA durante a interação planta-patógeno tem sido relatada de plantas para microorganismos patogênicos e simbióticos, de plantas para nematoides (Fire et al., 1998; Lilley et al. 2012), de fungos patogênicos para plantas (Singh et al., 2014; Nunes e Dean, 2012) e de plantas a insetos (Zhang et al. 2013). 


\subsection{HIGS (Host Induced Gene Silencing)}

A possibilidade de uma planta, expressando dsRNAs correspondentes a um gene do patógeno, conferir proteção à infecção a este patógeno, revolucionou o estudo de melhoramento de plantas a estresses bióticos. Este método biotecnológico, denominado por silenciamento gênico induzido pelo hospedeiro (HIGS), surge como uma alternativa promissora na proteção de plantas, pois combina uma alta seletividade para o organismo alvo, com efeitos colaterais mínimos ou até nulos, quando em comparação a outros tratamentos, como os químicos (Koch e Kogel, 2014).

Uma importante preocupação que se deve ter ao utilizar a técnica de HIGS é a escolha do gene alvo a ser silenciado, uma vez que nesta técnica a transformação ocorre no hospedeiro e o silenciamento no patógeno alvo. Não é desejado que ocorra efeito 'off target', ou seja, que possa ocorrer o silenciamento em alvos não desejados, sejam eles no hospedeiro ou em outros organismos que interajam com ele. Também é interessante que o gene escolhido tenha um fenótipo letal de knockout, não permitindo o completo desenvolvimento do patógeno em interação.

A obtenção de plantas que consigam silenciar um patógeno que venha a interagir com ela, é possível por meio da introdução da sequência do gene de interesse no sentido senso e antisenso (Waterhouse et al., 1998). Este tipo de construção, denominada de íntron-hairpin ou grampo de silenciamento, deve conter uma sequência de íntron flanqueada pela sequência de DNA desejada nos dois sentidos, de maneira que, durante sua transcrição seja formado o RNA dupla fita necessário para o início do processo de silenciamento por RNA.

O mecanismo de interferência de RNA está envolvido na defesa celular natural contra vírus. Muitas plantas são resistentes a vírus devido a ocorrência natural de dsRNA e siRNA cujos alvos são regiões gênicas virais importantes para o patógeno (Soler et al., 2012). Os vírus não apenas podem induzir o silenciamento, mas também são alvos do mecanismo, podendo ser mimetizado e introduzido em plantas de interesse, para gerar indivíduos resistentes ou imunes às viroses.

Os primeiros indícios da existência em plantas de um mecanismo de resistência específico contra vírus vieram dos estudos de resistência derivada do patógeno, que demonstraram que a expressão em plantas transgênicas de um fragmento do genoma viral tornava a planta resistente ao vírus que possui a sequência homóloga ao transgene (Lindbo e Dougherty, 1992). Bonfim et al. (2007) 
utilizando-se desta tecnologia, obtiveram plantas de feijão resistentes ao BGMV (Bean golden mosaic virus) a partir da introdução de uma sequência do gene viral que codifica um complexo funcional da proteína Rep. A Rep exerce uma função essencial no ciclo de infecção viral, sendo a única proteína requerida para a replicação do genoma deste vírus. Com o silenciamento deste gene, o vírus não conseguiu replicar no seu hospedeiro, não causando assim a doença. Isso levou ao desenvolvimento do evento Embrapa 5.1, gerando a primeira linhagem transgênica com tecnologia totalmente brasileira a ser aprovada para uso comercial. Outro exemplo do uso de HIGS para resistência a vírus foi a obtenção de plantas de lima mexicana (Soler et al., 2012) transformadas com um grampo de silenciamento contendo a versão intraduzível de genes do vírus da tristeza do citros (CTV) para silenciar a expressão destes genes (p25, p20 e p23). Sendo que três linhagens foram totalmente resistentes à infecção viral.

Este mecanismo de silenciamento gênico mediado por dsRNA não é restrito apenas contra vírus, sendo relativamente conservado em muitos eucariotos (Fire, 2007), em que as enzimas tipo Dicer RNase se ligam e digerem citoplasmaticamente dsRNAs em siRNAs.

\subsubsection{HIGS em insetos}

Desde a descoberta de que o silenciamento gênico por dsRNA é conservado em muitos organismos, este mecanismo tem sido demonstrado com sucesso em algumas espécies de insetos. Diversos são os estudos que demonstram que o silenciamento de um gene alvo específico pode levar o inseto a um descontrole de suas funções ou até mesmo à morte.

Bettencourt et al. (2002) utilizaram RNAi para investigar a função do gene hemolin, que codifica uma proteína presente em insetos relacionada à imunidade $\mathrm{e}$ pertencente à superfamília das imunoglobinas. Perceberam que quando fêmeas de Hyalophora cecropia eram inoculadas com dsRNA para este gene, quando acasaladas suas larvas não emergiam dos ovos e, quando verificados, os embriões apresentavam má formação. Com isso concluíram que Hemolin era necessário para o desenvolvimento e que o silenciamento deste gene levava à letalidade embrionária. Mais que isso, comprovaram que o mecanismo de silenciamento induzido por dsRNA, consequentemente por RNAi, era possível em insetos. No 
mesmo ano, Bucher et al. (2002) observaram um fenômeno similar em besouro castanho (Tribolium castaneum), em que dsRNAs injetados no hemoceloma de fêmeas, tinham seus embriões com genes zigóticos silenciados.

Uma das primeiras demonstrações de sucesso de HIGS em insetos foi reportado por Baum et al. (2007), que identificaram que a ingestão de dsRNAs fornecidos em dieta disparou o mecanismo de interferência por RNA em diversas espécies de coleópteros, podendo resultar em um déficit de crescimento e mortalidade das larvas. Com isso foi capaz de gerar plantas de milho expressando dsRNAs para v-ATPase direcionados à larva do besouro ocidental, que apresentaram uma redução no crescimento do dano causado por este inseto, uma vez que esta enzima é de importância para o crescimento e desenvolvimento do inseto.

Após esta data diversos foram os eventos demonstrando que o silenciamento induzido por RNA é possível em insetos, sejam eles das mais diversas ordens (Lepidoptera, Coleoptera, Diptera, Hemiptera Hymenoptera, Isoptera dentre outras), visando diferentes alvos (como por exemplo proteases, quitinases, v-ATPase, $\alpha$ tubulina, aminopeptidase, citocromo P450) e utilizando os mais diferentes mecanismos (injeção, alimentação e também plantas transformadas) (Zhang et al., 2013). Mais recentemente em nosso grupo, Ibrahim (2015), demonstrou que moscas brancas que se alimentaram de plantas de alface transformadas para silenciar 0 gene de uma v-ATPase destes insetos, apresentaram uma mortalidade maior e alterações no ciclo de desenvolvimento, demonstrando que tal silenciamento seria importante para o controle desta praga de grande importância para agricultura.

Portanto, a técnica de RNAi é considerada uma ferramenta em potencial para a proteção de culturas contra ataque de insetos. Esta é uma tecnologia que pode ser muito útil para o desenvolvimento de pesticidas de alta eficiência e baixa toxicidade, sendo uma boa alternativa tendo em vista o aumento do número de insetos resistentes a inseticidas tradicionais.

\subsubsection{HIGS em nematoides}

Nematoides parasitas de plantas causam enormes danos a diversas culturas de importância espalhadas em todo o mundo, chegando a causar grandes perdas econômicas aos produtores. Entretanto os métodos de controle, como nematicidas 
ou rotação de culturas são inadequados e podem gerar efeitos ambientais e econômicos diversos.

Em 1998, Fire et al., trabalhando com o nematoide Caenorhabditis elegans conseguiram demonstrar que o RNA fita dupla (dsRNA) foi substancialmente mais efetivo para produzir interferência do que uma fita de RNA individualmente. Isso foi conseguido através da injeção de RNA no verme, o que só foi possível pois este parasita possui todo o maquinário necessário para que ocorra a interferência por RNA, sendo então possível o silenciamento de genes por meio desta técnica. Este foi um importante trabalho que demonstrou o silenciamento gênico transcricional dependente de homologia e ainda que os dsRNAs foram mais eficientes para interferência que fitas simples de RNA.

Os dsRNAs podem ser disponibilizados diretamente no interior do parasita, por meio de micro injeções, através da alimentação com $E$. coli expressando dsRNA para genes alvo ou pela imersão do verme em uma solução contendo dsRNA (Kamath e Ahringer, 2003). Porém, além destes métodos in vitro de entrega de dsRNA, tem aumentado o número de experimentos que utilizam a produção in planta de dsRNA de genes alvos dos nematoides.

Em 2002, Urwin et al., conseguiram silenciar genes em nematoides dos cistos em fase juvenil J2, abrindo a possibilidade para que o RNAi seja usado como ferramenta para genômica funcional e também como estratégia para controle a partir de plantas transgênicas.

Os sítios de alimentação de nematoides fitoparasitas sedentários se apresentam como uma rota ideal para direcionar os dsRNAs, uma vez que se alimentam durante todo seu desenvolvimento, o que permite a entrega continua de dsRNA/siRNA durante todo o ciclo de vida do parasita.

Ainda não está claro se os nematoides ingerem siRNAs da planta ou os dsRNAs não processados, e subsequentemente são processados em siRNAs pelas enzimas DICER do parasita (Gheysen e Vanholme, 2007).

Alguns trabalhos têm mostrados resultados extremamente promissores utilizando plantas transformadas para atingir genes alvo de nematoides. Huang et al. (2006) conseguiram por meio da transformação de $A$. thaliana alto nível de resistência ao nematoide das galhas. DsRNA complementar ao gene 16D10, gene de parasitismo, era expresso nas plantas transformadas, resultando em uma redução significativa (63 a 90\%) do numero de galhas e produção total de ovos do 
parasita. Devido ao alto grau de homologia entre as sequências de $16 D 10$ de diferentes espécies de Meloidogyne houve uma ampla gama de resistência a $M$. incógnita, M. javanica, M. arenaria e M. hapla.

Outro trabalho que demonstrou HIGS utilizando nematoides e plantas foi o de Ibrahim et al. (2011) que trabalhando com soja, estudaram quatro genes diferentes a fim de determinar sua eficácia na redução de formação de galhas causadas por $M$. incógnita em raízes de soja. Identificaram duas construções promissoras, a que tinha como alvo o gene da tirosina fosfatase (TP) e outra para o precursor da proteína mitocondrial stress-70 (MPS). Estas interferiram fortemente na formação de galhas, com redução de $92 \%$ e 94,7\%, respectivamente.

Estes trabalhos são um exemplo de como HIGS em nematoides pode ser uma boa ferramenta para ser usada no controle e estudo deste parasita tão importante para agricultura mundial.

\subsubsection{HIGS em plantas parasitas}

O primeiro trabalho que demonstrou a possibilidade do sinal de silenciamento ser passado de uma planta para outra foi realizado por Tomilov et al. (2008), que trabalhando com alface e seu parasita Triphysaria versicolor conseguiu demonstrar que os sinais de silenciamento para o gene repórter GUS era passado da planta parasita para a hospedeira e vice e versa. Com esta evidencia diversos trabalhos foram desenvolvidos com a finalidade de gerar plantas resistentes a plantas parasitas com o silenciamento de genes envolvidos na interação planta-hospedeiro.

Foi o que aconteceu no trabalho de Aly et al. (2009) que transformando plantas de tomate para o silenciamento de um gene da biossíntese de manitol (M6PR) da planta parasita Orobanche aegyptiaca, obteve uma redução de 60\% a $80 \%$ no crescimento da parasita e um decréscimo do nível de manitol, aumentando o percentual de mortalidade da parasita quando em contato com a planta transformada. Desta forma a planta de tomate ficava tolerante a esta planta parasita.

A planta parasita cuscuta (Cuscuta pentagona) estabelece uma junção simplástica, via haustorium, com seu hospedeiro para conseguir acesso à água e nutrientes. A transferência bidirecional de milhares de mRNAs entre a cuscuta e seu hospedeiro tem sido observada. Com este conhecimento Alakonya et al. (2012) conseguiram interromper o crescimento da planta parasita através da transformação 
de plantas de tabaco, expressando RNAi para o gene STM (Shoot Meristemless) de cuscuta. Análises das plantas parasitas revelaram a presença de sRNAs correspondentes a construção de RNAi e a expressão de STM reduzida, causando assim uma substancial diminuição no crescimento da parasita após o parasitismo na planta de fumo transformada. Entretanto, o destino e a função destes mRNAs transferidos continuam não compreendidos, por exemplo se estes transcritos transferidos são translocados em proteínas funcionais, ou são degradados como recurso nutricional (Weiberg et al., 2015).

\subsubsection{HIGS em fungos}

Exemplos de aplicação do silenciamento por RNA em interações planta-fungo têm surgido bastante recentemente. $O$ uso de HIGS para combater patógenos fúngicos geralmente causam alterações na morfologia dos fungos, inibição de seu crescimento in planta e, mais importante, diminuição de sua virulência.

Em 2010 nosso grupo comprovou pela primeira vez a possibilidade de transferência do sinal de silenciamento de uma planta para um fungo fitopatogênico (Tinoco et al. 2010). Foi demonstrado que o sinal para silenciar um gene repórter (gus) gerado na planta de tabaco (siRNAs), foi translocado para as células do fungo (Fusarium) geneticamente modificado para expressar o gene gus. Verificou-se que 0 gene gus foi silenciado nas células do fungo quando este interagia com a planta. Desta forma, abriu-se a possibilidade de gerar plantas resistentes pelo silenciamento in trans de genes específicos e fundamentais para o metabolismo de fungos fitopatogênicos.

HIGS também foi verificado em cevada expressando dsRNA que teve como alvo o gene efetor Avra10 do fungo patogênico Blumeria graminis (Nowara et al., 2010). Com esta estratégia foi possível obter plantas de cevada resistente a Blumeria. Singh et al. (2014) demonstraram a eficácia da utilização de HIGS ao transformar plantas de tomate com hairpin de silenciamento para o gene ornitina descarboxilase (ODC) do patógeno causador da murcha por fusariose (Fusarium moniliforme), e assim obtiveram linhagens transgênicas com moderada a alta resistência ao Fusarium. Com estes estudos e outros estudos ficou comprovada a eficiência da técnica de HIGS em plantas para o silenciamento de fungos patogênicos. 
Os exemplos de HIGS relatado até agora confirmam a hipótese de que pequenos RNAs são capazes de mover-se de plantas para células fúngicas e efetivamente silenciar seus genes-alvo. Portanto, com a possibilidade de silenciamento in trans, pela expressão de um dsRNA em plantas, para silenciar um gene em um fungo que interaja com essa, surge a possibilidade de desenvolvimento de uma estratégia para geração de plantas resistentes a fungos. Uma etapa chave neste processo é a escolha das melhores opções para expressão dos genes nas plantas e daqueles genes vitais para o ciclo celular das células fúngicas. Vários candidatos podem ser apontados, mas resta a pergunta se seria possível HIGS com estes genes, devido à similaridade entre sequências de genes de plantas e fungos.

\subsection{Parede celular e Quitina}

A parede celular é uma estrutura essencial que mantém a viabilidade da célula fúngica, conferindo sua morfologia típica e protegendo contra injúrias externas. A parede celular é a estrutura detectada pelas células do hospedeiro responsáveis pelo desencadeamento e organização de toda a resposta imune inata e adaptativa contra o patógeno. A parede celular dos fungos se torna então um alvo promissor para descoberta de medicamentos ou outras estratégias que possam inibir a infecção e desenvolvimento do fungo. $E$ isso se dá devido a alguns fatores, dentre eles a exclusividade, ou seja, o fato de que a parede celular é única para o fungo, cumprindo o requisito de seletividade. Outro importante fator é que é a estrutura mais externa presente na célula fúngica e, portanto, possui um papel crucial na interação com as células hospedeiras, mediando processos como adesão, colonização, sinalização e reconhecimento imunitário, sendo muito importante durante o processo de infecção. E, mais relevante, é que é uma estrutura essencial para a célula, cuja inibição pode conduzir à lise e até morte celular (Arana et al., 2009). Pelo exposto, interrupções da estrutura da parede celular têm um profundo efeito no crescimento e na morfologia da célula fúngica. Dado esse papel essencial que a parede celular desempenha na fisiologia dos fungos, a parede tem sido considerada um excelente alvo para agentes antifúngicos (Bowman e Free, 2006).

A parede celular de fungos é estruturalmente única e difere significativamente da parede celular de plantas, baseada em celulose. A parede celular de fungos é composta por polissacarídeos e glicoproteínas, principalmente glucano e quitina. E já foi mostrado que quando a síntese de quitina é interrompida, a parede se torna 
desordenada e a célula fúngica malformada e osmoticamente instável (Bago et al., 1996; Specht et al., 1996).

Quitina é um componente essencial em células da parede e dos septos de todos fungos patogênicos, entretanto ausente em vertebrados e plantas. Com isso, é menor a possibilidade de ocorrência de efeitos "off-target" em plantas modificadas para silenciar genes da via de síntese de quitina. Esta é uma diferença crucial para considerarmos quitina como alvo seguro e seletivo para o desenvolvimento de agentes de controle antifúngicos (Martín-Udíroz, 2004).

A quitina é um polímero de $\beta-1,4 \mathrm{~N}$-acetilglicosamina, sintetisado por uma grande família de enzimas quitina sintase (CHS), enzimas de membrana que catalisam a transferência de $\mathrm{N}$-acetilglicosamina de uma uridina difosfato (UDP) a uma cadeia crescente de quitina (Bowman e Free, 2006). As CHS pertencem à família das glicosiltransferases, que estão compreendidas em sete classes (Leonardon et al., 2010). Estão localizadas em membranas do Complexo de Golgi, na membrana plasmática, bem como em vesículas intracelulares, como os quitossomos, que são responsáveis pelo transporte das $\mathrm{CHS}$ do retículo endoplasmático para a superfície celular (Roncero, 2002; Specht et al., 1996).

A quitina é reconhecida como um elicitor de respostas de defesa das plantas. A infecção fúngica, induz a expressão de quitinases em células vegetais. As quitinases são enzimas responsaveis pela degradação da quitina, elas clivam as ligações glicosídicas $\beta-1,4$ presentes nos polímeros e se acumulam no local da invasão. Além do efeito direto de limitar a invasão de fungos por hidrolisar a parede celular, os fragmentos de quitina resultantes (quitooligossacarídeos) também parecem funcionar como elicitores de numerosos genes de resposta secundária (Eckardt, 2008).

O estudo e a caracterização de genes envolvidos no metabolismo de quitina (síntese e degradação) darão suporte ao desenvolvimento de estratégias de controle de fitopatógenos, bem como possibilitará um avanço na compreensão da biologia desses fungos. Devido à integridade estrutural que a quitina fornece à célula fúngica, a síntese de quitina tem sido considerada um excelente alvo para agentes antifúngicos. 


\section{Objetivos}

O principal objetivo deste trabalho foi o silenciamento do gene da quitina sintase em Sclerotinia sclerotiorum por meio de HIGS, quando inoculado em uma planta de fumo transgênica, podendo obter assim, plantas resistentes ao mofo branco.

\subsection{Objetivos Específicos}

- Obter uma construção do tipo intron-hairpin para o silenciamento do gene da quitina sintase de fungos fitopatogênicos;

- Obter plantas de fumo geneticamente modificadas contendo o grampo de silenciamento para o gene da quitina sintase;

- Mostrar que os sinais de silenciamento estão sendo formados;

- Avaliar o comportamento do fungo após contato com a planta transformada. 


\section{Material e Métodos}

\subsection{Construção do RNAi e transformação de plantas}

Um fragmento contendo uma sequência parcial do gene de quitina sintase (chs) classe VII de Fusarium verticillioides foi amplificado por PCR. O par de primers ChirnaiF (5'-AGGGCCCGGTACCTTCAGCGTATGCC-3') e ChirnaiR (5'AGAGCTCTCTAGAGGCCAATCGAGGG-3') (incluindo os sítios para Xba I/Sac I e Kpn I/Apa I, respectivamente) foi usado para amplificar um fragmento de $494 \mathrm{pb}$ do gene da quitina sintase CHS7 (posição 624 a1.117 no GenBank número de acesso GU066261.1). O gene de $F$. verticillioides possui $67 \%$ de identidade com o gene da quitina sintase de $S$. sclerotiorum (Sschs). Reações de PCR foram realizadas em termociclador (MyCycler, Thermal Cycler, BioRad, EUA) em uma solução de $50 \mu \mathrm{L}$ contendo $40 \mathrm{ng}$ de cDNA, $60 \mathrm{mM}$ de Tris-SO $\mathrm{SO}_{4}(\mathrm{pH} 8.9), 18 \mathrm{mM}$ de $\left(\mathrm{NH}_{4}\right)_{2} \mathrm{SO}_{4}, 2 \mathrm{mM}$ de $\mathrm{MgSO}_{4}, 250 \mathrm{nM}$ de cada dNTP, $200 \mathrm{nM}$ de cada primer e 5U de Taq DNA polimerase platinum high fidelity (Invitrogen, Carlsbad, CA, U.S A.). A mistura foi tratada a $94^{\circ} \mathrm{C}$ ( $1 \mathrm{~min}$ ) e submetida a 40 ciclos de amplificação $\left(94^{\circ} \mathrm{C}\right.$ por $1 \mathrm{~min}, 60^{\circ} \mathrm{C}$ por $1 \mathrm{~min}$ e $68^{\circ} \mathrm{C}$ por $1 \mathrm{~min}$ ), com um ciclo de alongamento final de $7 \mathrm{~min}$ a $68^{\circ} \mathrm{C}$. $\mathrm{O}$ fragmento foi clonado no vetor pGEMT-Easy para produtos de PCR (Promega Corp., Madison, WI, U.S.A.) e sequenciado utilizando primers universais de M13 e T7 em sequenciador automático (ABI Prism1 3700). Após sua identificação, o fragmento de interesse (chs) foi clonado no vetor de silenciamento pSIU (Tinoco et al., 2010) entre os sítios Xba I e Kpn I. Para a formação do grampo de interferência, a mesma sequência foi clonada, porém agora no sentido invertido, entre os sítios Apa I e Sac I, gerando o vetor pSIUSynchit2. O cassete de interferência foi retirado com as enzimas EcoR I e Hind III e inseridos no vetor pCambia1301, que contém os genes gus e hpt (que confere tolerância à higromicina), para gerar o vetor final (pCAMBIASynchit2). $O$ cassete de interferência contém a sequência de chs nos dois sentidos, com um íntron 3 do gene da malato sintase de Arabidopsis thaliana (i3), sob o controle do promotor 35S RNA do vírus do mosaico da couve-flor (35S) e a sequência enhancer de alfafa mosaic vírus (AMV), e o terminador do gene nos (nos3'). O vetor final, pCAMBIASynchit2 foi usado para transformar a estirpe LBA4404 de Agrobacterium tumefaciens por eletroporação. A Agrobacterium, contendo o vetor pCAMBIASynchit2, foi usada para transformação de Nicotiana 
tabacum (cv. Xanthi) conforme descrito por Horch et al. (1985). O cassete contendo o grampo de silenciamento com a sequência chs foi denominado por $\Delta c h s$ (Figura $1 \mathrm{~A})$.

\subsection{Avaliação de Plantas Transformadas por PCR}

A análise molecular visando à detecção de $\Delta c h s$, foi realizada utilizando o DNA extraído de discos foliares, de acordo com Edwards et al. (1991). Para cada amostra analisada, $2 \mu \mathrm{L}$ de DNA ( $\approx 20 \mathrm{ng}$ ) foram adicionados à solução contendo 17,6 $\mu \mathrm{L}$ de $\mathrm{H}_{2} \mathrm{O} ; 2,5 \mu \mathrm{L}$ de tampão 10X; 0,8 $\mu \mathrm{L}$ de dNTP $(4 \mu \mathrm{M}) ; 0,6 \mu \mathrm{L}$ de $\mathrm{MgCl}_{2}(50 \mu \mathrm{M}) ; 0,5$ $\mu \mathrm{L}$ de cada primer $(10 \mu \mathrm{M})$; e $0,5 \mu \mathrm{L}$ de Taq polimerase $(10 \mathrm{U} / \mu \mathrm{L})$. Os primers Chirnaif (5'-AGGGCCCGGTACCTTCAGCGTATGCC-3') e ChirnaiR (5'AGAGCTCTCTAGAGGCCAATCGAGGG-3') utilizados na reação amplificam uma sequência de $520 \mathrm{pb}$ contidas em $\Delta c h s$ (sequência chs mais os sítios das enzimas de restrição).

As reações de PCR foram realizadas em termociclador (MyCycler, Thermal Cycler, BioRad, USA), seguindo a temperatura inicial de desnaturação de $94^{\circ} \mathrm{C}$ por 5 min, 35 ciclos a $94^{\circ} \mathrm{C}$ de desnaturação por $1 \mathrm{~min}, 58^{\circ} \mathrm{C}$ de alinhamento dos primers por $1 \mathrm{~min}$, extensão a $72^{\circ} \mathrm{C}$ por $1 \mathrm{~min}$, e extensão final a $72^{\circ} \mathrm{C}$ por 5 min.

Os produtos da PCR foram submetidos à eletroforese em gel de agarose $1 \%$ usando tampão TBE $0,5 \mathrm{X}$ e voltagem ajustada para $5 \mathrm{~V} / \mathrm{cm}$.

\subsection{Análise da progênie}

Sementes da primeira geração de plantas transformadas $\left(T_{1}\right)$, provenientes de auto-fecundação das plantas $T_{0}$ foram germinadas em substrato ( $80 \%$ solo e $20 \%$ vermiculita) e mantidas em casa-de-vegetação. Estas foram analisadas para presença de $\Delta$ chs por reações de PCR conforme descrito acima e também pelo ensaio histoquímico para detectar a expressão do gene GUS de acordo com Jefferson et al. (1987). Análises de Qui-quadrado $\left(x^{2}\right)$, utilizando o fator de correção de Yates (Steel e Torrie, 1980), foram feitas para determinar se a segregação observada seguia um padrão Mendeliano na razão de 3:1 ou 15:1, com 95\% de nível de confiança. 


\subsection{Bioensaios}

Os bioensaios foram realizados com folhas destacadas provenientes de plantas da geração $T_{1}$, pré-selecionadas por PCR ou teste histoquímico de X-gluc. Foram coletadas folhas novas, com aproximadamente 45 dias de idade, a terceira folha mais nova totalmente expandida, sempre mantendo um tamanho padrão. Os escleródios foram obtidos em campos de feijão em Goiás/Brasil, desinfestados com hipoclorito a $1 \%$ por 5 min e colocados para crescimento em meio PDA (potato dextrose agar) sob temperatura ambiente, até formação de micélio. Da região de crescimento do micélio, foram retirados plugs de $5 \mathrm{~mm}$ de diâmetro, que foram inoculados na face adaxial de folhas de tabaco destacadas. As folhas foram mantidas em câmara úmida, sob temperatura de $20^{\circ} \mathrm{C}$, no escuro. As folhas foram fotografadas em dois tempos diferentes (48 e 72h após inoculação), a fim de acompanhar o desenvolvimento do fungo quando em contato com a planta. As imagens foram usadas para a medida da área infectada com a utilização do software QUANT v1.0.1 (Vale et al., 2003). As médias da área lesionada foram agrupadas pelo teste de Scott \& Knott (1974), com 5\% de probabilidade, utilizando o software estatístico R (v. 3.1.2) (disponível em www.R-project.org/). Os experimentos foram repetidos duas vezes, com um total de quatro repetições.

\subsection{Análise de siRNAs}

O RNA total foi isolado de folhas de plantas de tabaco (geração $T_{2}$ ) utilizando o método do cloreto de lítio de acordo com Aragão et al. (2013), onde além de utilizar fenol ácido:clorofórmio:álcool isoamílico (25:24:1), faz-se uma precipitação com LiCl a 4M. As análises de siRNA foram feitas de acordo com Tinoco et al. (2010), com a ressalva de que foram utilizados $60 \mu \mathrm{g}$ de RNA. Como sonda, foi utilizado o próprio fragmento chs, obtido por amplificação por PCR utilizando o par de primers específicos (ChirnaiR/Chirnaif). A sonda foi marcada com a ${ }^{32} \mathrm{P}$ dCTP utilizando um kit de marcação de DNA com primers aleatórios (Amersham Pharmacia Biotech) de acordo com as orientações do fabricante. Como marcador molecular de tamanho foram utilizados três oligômeros (18, 24 e 44 nucleotídeos). As bandas foram visualizadas com um analisador de imagem fluorescente (FLA-3000; Fujifilm). 


\subsection{Análise de PCR quantitativo em tempo real}

A expressão do gene endógeno Sschs foi analisada na interação do micélio de S. sclerotiorum com folhas de plantas transformadas (geração $T_{2}$ ) por PCR quantitativo em tempo real. Para obtenção do RNA total do fungo, foi realizado um bioensaio nos moldes anteriormente apresentados, com as plantas transformadas $\mathrm{e}$ um controle, e coletado após $96 \mathrm{~h}$ de crescimento. A área de coleta limitou-se à lesão apresentada pelo crescimento do fungo, para que assim fossem adquiridos micélios que já tivessem entrado em contato com a planta. A extração do RNA total do fungo foi feita com Trizol (Invitrogen), seguindo as recomendações do fabricante. O DNA genômico remanescente foi eliminado pelo tratamento das amostras de RNA com DNase. O RNA total foi usado para produzir o cDNA utilizando a transcriptase reversa Superscript III (Promega), de acordo com o protocolo do fabricante. As reações de PCR foram realizadas em um sistema de PCR em tempo real Applied Biosystems 7300 utilizando SybrGreen (Stratagene), de acordo com as instruções do fabricante. O programa utilizado para amplificação foi de $94^{\circ} \mathrm{C}$ por $15 \mathrm{seg}, 58^{\circ} \mathrm{C}$ por $15 \mathrm{seg}$ e $72^{\circ} \mathrm{C}$ por $15 \mathrm{seg}$. Foram utilizados os primers RT-Synchit1F (5'TCGTATCTGGGTCGCTATCA-3') e RT-Synchit1R (5'TGCGTACATCTGGATGTTTC-3') para amplificar um fragmento de $95 \mathrm{pb}$ dentro do gene da quitina sintase em Sclerotinia sclerotiorum (Sschs) (XM001584969.1). Como controle interno foram utilizados primers do gene da alpha tubulina de $S$. sclerotiorum (Ssa-tubulin), 5'-GTCGGTGAAGGTATGGAAGAAG-3' (RTAlphaTubulinF) e 5'-CCTCTTCAGCCTCAAAGCTATC-3' (RT-AlphaTubulinR), produzindo uma banda de 109 pb (XM001597572.1). Portanto o nível de transcrição relativo a Sschs em diferentes amostras de RNA, foi normalizado em relação ao gene Ssa-tubulin, utilizado como controle interno. Os primers foram desenhados com o auxílio da ferramenta PrimerQuest Tool (IDT Integrates DNA Technologies, Inc.).

Os produtos obtidos da reação de PCR foram separados por eletroforese em gel de agarose e sequenciados para confirmação de sua identidade. Ensaios quantitativos em triplicata foram realizados em cada amostra de cDNA. O nível relativo de expressão foi calculado usando o método de Livak (Livak e Schmittgen, 2001). Os resultados obtidos foram comparados por ANOVA one-way com teste de Dunnett $(\alpha=0,05)$ para analisar as diferenças entre cada isolado, que interagiu com 
cada evento da planta, relativo ao controle, usando o software estatístico $R$ (v. 3.1.2) disponível em www.R-project.org/. 


\section{Resultados}

A construção de primers específicos para a sequência da quitina sintase de Sclerotinia sclerotiorum (ChirnaiR e ChirnaiF) permitiu sua identificação para posterior clonagem no vetor de interferência pSIU.

Foram obtidas 36 plantas de tabaco a partir da transformação por Agrobacterium com o vetor final pCAMBIASynchit2, crescendo em meio de seleção com antibiótico específico (higromicina) para a seleção de células transformadas. Análises de PCR confirmaram a inserção de $\Delta c h s$ em 28 plantas $T_{0}$, demonstrando assim uma alta eficácia na transformação. As plantas positivas pelo PCR foram aclimatadas e apresentaram-se fenotipicamente normais quando comparadas ao controle. Todas as plantas aclimatadas (geração $\mathrm{T}_{0}$ ) produziram sementes, obtendo a próxima geração $\left(T_{1}\right)$. As sementes da geração $T_{1}$ deram origem a plantas também fenotipicamente semelhantes à planta controle. Na Figura 1B estão representadas bandas referentes a 14 plantas que se apresentaram positivas pela reação de PCR, revelando assim a presença do cassete de interferência $\Delta$ chs.

$O$ bioensaio feito com as plantas da geração $T_{1}$ inoculadas com Sclerotinia, a fim de demonstrar o efeito in vivo do silenciamento gerado pela planta no fungo, mostrou que algumas delas apresentaram uma maior tolerância à colonização pelo fungo. A leitura da área afetada pelo crescimento do fungo foi realizada através das imagens capturadas a 48 e $72 \mathrm{~h}$ após a inoculação. Os resultados mostraram que algumas linhagens transgênicas apresentaram um atraso no desenvolvimento do sintoma quando comparadas à linhagem não transgênica. A área infectada às $72 \mathrm{~h}$ após a inoculação do fungo variou de $2,2 \mathrm{~cm}^{2}$ a $20,0 \mathrm{~cm}^{2}$ (média de $11,1 \mathrm{~cm}^{2}$ ) nas linhagens transgênicas, enquanto que no controle (plantas não transgênicas) a área infectada variou de $13,1 \mathrm{~cm}^{2}$ a $23,1 \mathrm{~cm}^{2}$ (média de 16,8 $\mathrm{cm}^{2}$ ). Não foram observadas diferenças significativas entre plantas não transgênicas e plantas transformadas com o vetor pCAMBIA1301 vazio, ou seja, sem o cassete $\Delta$ chs (Tabela 1 ). 

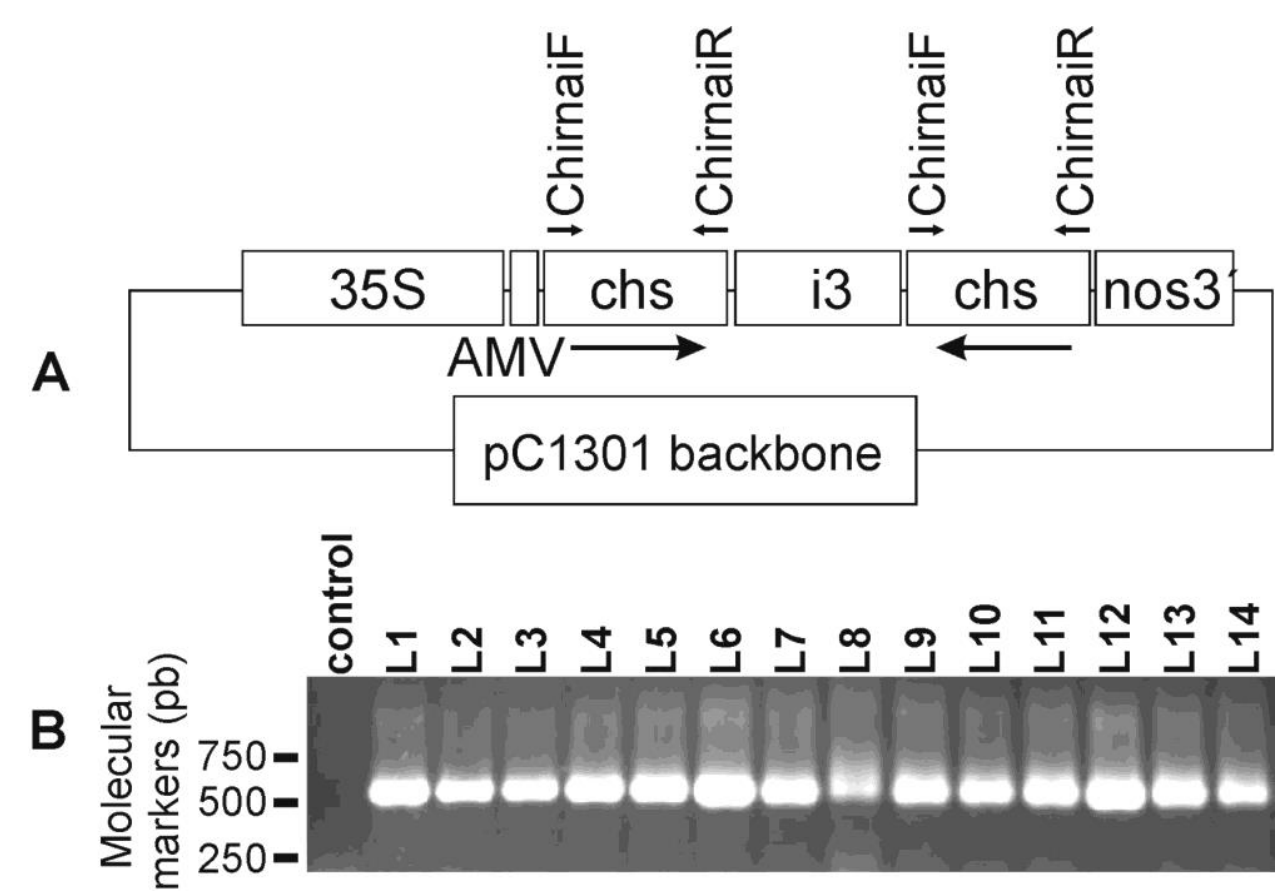

Figura 1. (A) Diagrama de representação do vetor para expressar dsRNA em plantas de tabaco transgênicas com o vetor pCAMBIASynchit2. O cassete de interferência $(\Delta c h s)$ está sob controle do promotor 35S RNA do vírus do mosaico da couve-flor (35S) e uma sequência enhancer do Alfalfa mosaic virus (AMV). O fragmento do gene da quitina sintase de $F$. verticillioides (chs) foi clonado na direção sense e anti-sense, flanqueando o íntron 3 do gene da malato sintase de Arabidopsis thaliana (i3). O cassete foi clonado em um vetor pC1301 gerando pCAMBIASynchit2 que foi usado na transformação de plantas de fumo. (B) Análise de PCR de 14 plantas transformadas com o vetor pCAMBIASynchit2 (L1 a L14) para detecção da sequência chs (utilizando o par de primers ChirnaiR/ChirnaiF). O controle é uma planta não transformada.

A análise de segregação revelou que o transgene estava segregando em proporção mendeliana nas 10 linhagens selecionadas. Linhagens L6, L9, L10, L11 e L13 apresentaram a taxa de segregação de 3:1, indicando ser controlado por um loco somente. As linhagens L5, L7, L8, L12 e L14 apresentaram a segregação de 15:1, indicando dois locos estarem envolvidos no controle desta característica. Entretanto as linhagens L1, L2, L3 e L4 não apresentaram segregação mendeliana (Tabela1). 
Tabela 1. Análise da segregação e progressão da doença em linhagens transgênicas e controles (plantas não transgênicas e plantas transformadas com o vetor pCAMBIA1301 sem o cassete $\Delta c h s-82 \mathrm{C}$ ) $48 \mathrm{~h}$ e $72 \mathrm{~h}$ após a inoculação com micélio de $S$. sclerotiorum em plug de ágar.

\begin{tabular}{cccccccc}
\hline \multirow{2}{*}{ Linhagem } & \multicolumn{2}{c}{ Área lesão $\left(\mathrm{cm}^{2}\right)^{*}$} & \multicolumn{2}{c}{ Geração $T_{1}^{* *}$} & \multirow{2}{*}{$\begin{array}{c}\text { Teste de } \\
\text { Segregação }\end{array}$} & $X^{2}$ & $P^{* * *}$ \\
\cline { 2 - 7 } & 48h & 72h & Positivo & Negativo & & \\
\hline L13 & $6.35 \pm 3.12 \mathrm{a}$ & $20.00 \pm 5.20 \mathrm{a}$ & 13 & 7 & $3: 1$ & 0.87 & 0.30 \\
L8 & $5.15 \pm 1.41 \mathrm{a}$ & $19.13 \pm 4.03 \mathrm{a}$ & 18 & 2 & $15: 1$ & 0.13 & 0.49 \\
L12 & $7.19 \pm 3.01 \mathrm{a}$ & $19.04 \pm 5.03 \mathrm{a}$ & 18 & 2 & $15: 1$ & 0.13 & 0.49 \\
L9 & $5.31 \pm 2.16 \mathrm{a}$ & $15.99 \pm 2.66 \mathrm{a}$ & 16 & 4 & $3: 1$ & 0.47 & 0.61 \\
L11 & $4.52 \pm 0.34 \mathrm{a}$ & $14.13 \pm 1.24 \mathrm{a}$ & 13 & 7 & $3: 1$ & 0.87 & 0.30 \\
L10 & $3.92 \pm 0.35 \mathrm{a}$ & $13.32 \pm 2.17 \mathrm{a}$ & 14 & 6 & $3: 1$ & 0.20 & 0.61 \\
L14 & $3.67 \pm 0.32 \mathrm{a}$ & $12.71 \pm 2.09 \mathrm{a}$ & 18 & 2 & $15: 1$ & 0.13 & 0.49 \\
L2 & $2.88 \pm 0.86 \mathrm{a}$ & $11.95 \pm 1.08 \mathrm{a}$ & 6 & 14 & $3: 1$ & 20.47 & 0.00 \\
L1 & $2.65 \pm 0.07 \mathrm{a}$ & $11.20 \pm 0.12 \mathrm{a}$ & 4 & 16 & $3: 1$ & 30.87 & 0.00 \\
\hline L4 & $2.22 \pm 0.16 \mathrm{a}$ & $7.45 \pm 1.84 \mathrm{~b}$ & 6 & 14 & $3: 1$ & 20.47 & 0.00 \\
L5 & $1.64 \pm 0.85 \mathrm{a}$ & $3.49 \pm 1.55 \mathrm{~b}$ & 18 & 2 & $15: 1$ & 0.13 & 0.49 \\
L6 & $1.10 \pm 0.12 \mathrm{a}$ & $2.76 \pm 0.21 \mathrm{~b}$ & 16 & 4 & $3: 1$ & 0.47 & 0.61 \\
L3 & $1.02 \pm 0.07 \mathrm{a}$ & $2.65 \pm 0.37 \mathrm{~b}$ & 3 & 17 & $3: 1$ & 36.87 & 0.00 \\
L7 & $1.39 \pm 0.59 \mathrm{a}$ & $2.23 \pm 0.51 \mathrm{~b}$ & 18 & 2 & $15: 1$ & 0.13 & 0.49 \\
\hline 82C & $4.02 \pm 1.34 \mathrm{a}$ & $14.47 \pm 1.87 \mathrm{a}$ & & & & & \\
Controle & $5.10 \pm 2.37 \mathrm{a}$ & $16.76 \pm 2.83 \mathrm{a}$ & & & & & \\
\hline
\end{tabular}

*Médias seguidas pela mesma letra, nas colunas, não diferem significativamente entre si pelo teste Scott-Knott, a 5\% probabilidade. Experimentos foram repetidos duas vezes, $n=4$. ** Dados baseados em análises de PCR para detecção de $\Delta c h s$ e por ensaios histoquímicos de GUS.

${ }^{\star * *} P$, probabilidade que os valores observados reflitam a segregação esperada de $3: 1$ ou $15: 1$.

Considerando a média das três melhores linhagens neste ensaio ( $L 7, L 3, L 6)$, houve uma redução na severidade da doença de $86,7 \%, 84,2 \%$ e $83,5 \%$, respectivamente. Mesmo assim, o teste de Scott-Knott não revelou diferenças significativas entre as linhagens transgênicas e o controle após 48h de inoculação. Contudo, cinco linhagens (L3, L4, L5, L6 e L7) mostraram uma diferença significativa na área da lesão à $72 h$, que não mostrou grande progresso após este tempo (Tabela 1, Figuras 2 e 3). A área da lesão continuou a crescer no controle não transgênico, alcançando as bordas da folha (Figura 3). Não foi observado uma correlação entre o número de locos transgênicos e a tolerância à $S$. sclerotiorum (Tabela 1). 

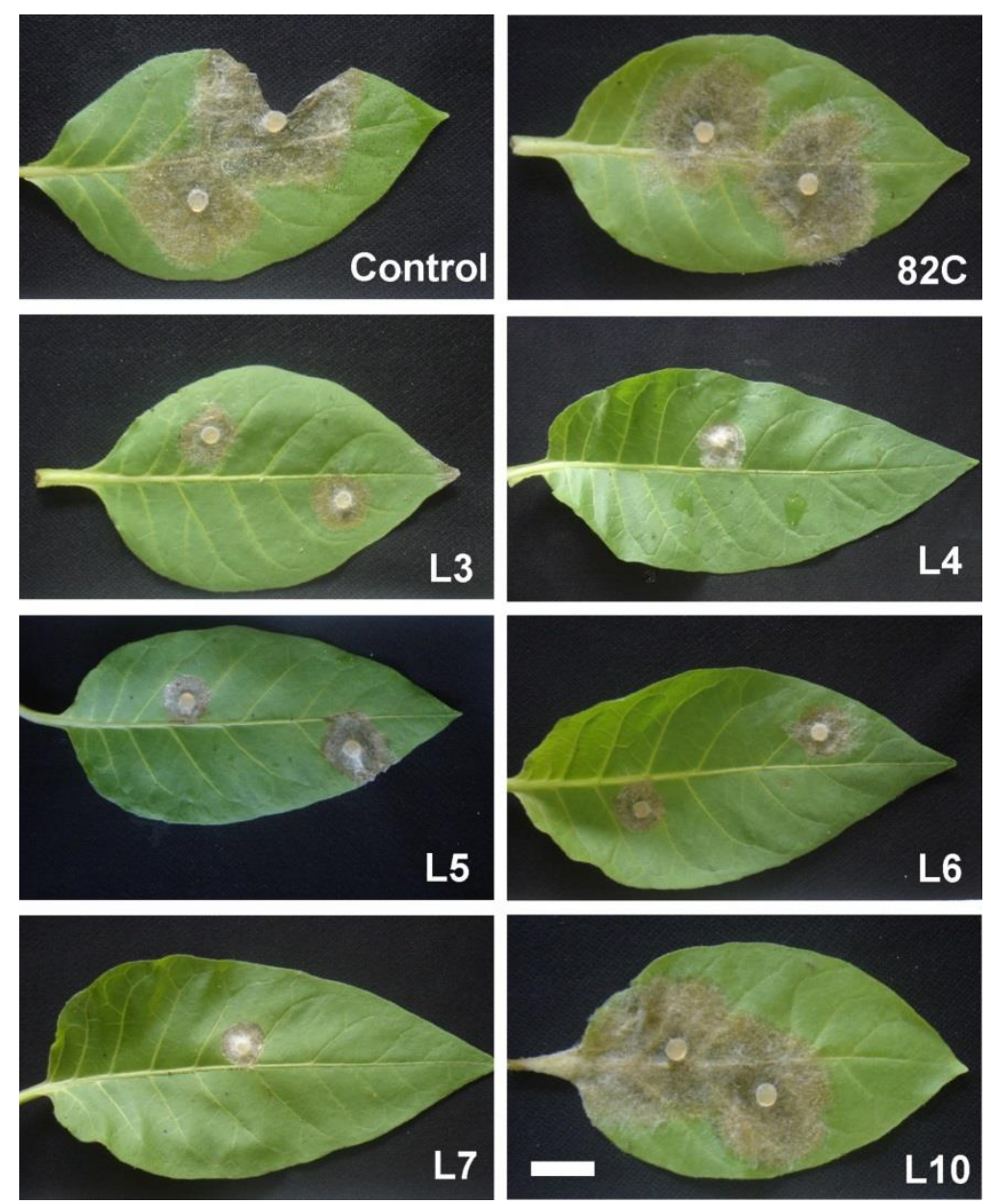

Figura 2. Resposta de plantas transgênicas à inoculação de $S$. sclerotiorum.

Sintomas observados após $72 \mathrm{~h}$ de inoculação, em folhas destacadas de linhagens transgênicas e não transgênicas (controle). A linhagem $82 \mathrm{C}$ é transformada com pCAMBIA1301 sem o cassete $\Delta$ chs. Barra $=2 \mathrm{~cm}$.

Figura 3. Detalhe da linhagem L5 à resposta ao
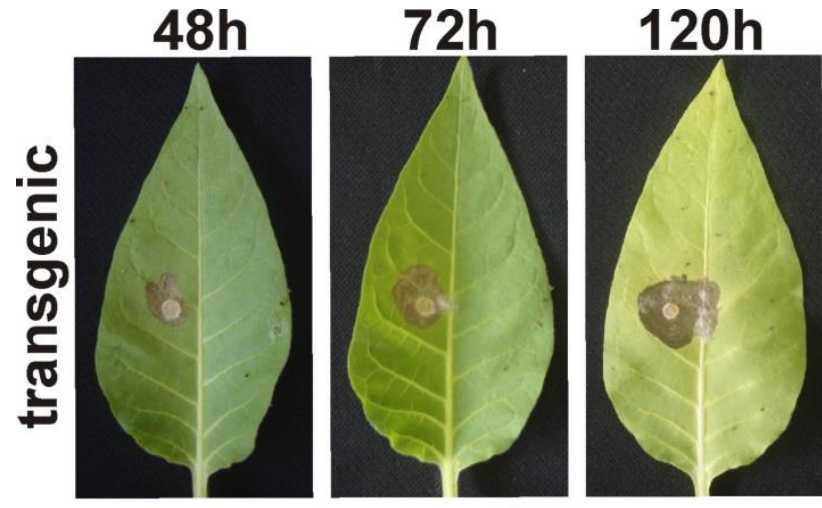
crescimento do micélio após $48 \mathrm{~h}, 72 \mathrm{~h}$ e $120 \mathrm{~h}$ comparada à planta controle, demonstrando que a área lesionada não apresentou uma progressão com o avanço do tempo (até 120h) quando comparada à planta não transgênica. Barra $=2 \mathrm{~cm}$
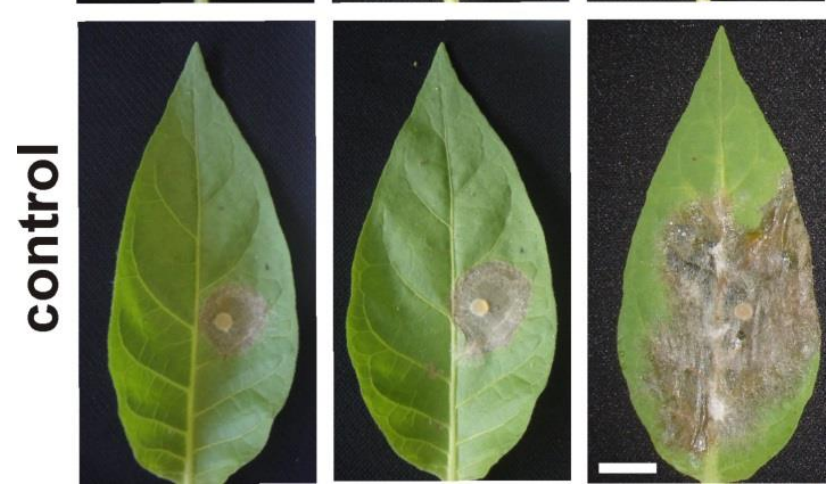
Análises de Northern Blot foram realizadas para detectar os siRNAs em folhas de plantas transgênicas e não transgênicas. A análise demonstrou a presença de bandas de siRNA do tamanho esperado nas linhagens L3, L4, L5, L6 e L7. Nenhum sinal detectável foi observado em outros eventos transgênicos ou na linhagem controle (Figura 4). Estes resultados mostram uma correlação positiva entre a presença de siRNA detectável e redução da severidade da doença após a inoculação com S. sclerotiorum.

A análise de RT-PCR quantitativo foi realizada para verificar a relação entre o silenciamento do gene da quitina sintase em Sclerotinia induzido por siRNAs específicos a Sschs produzidos pelo hospedeiro e o comprometimento da capacidade do fungo de colonizar o tecido do hospedeiro. S. sclerotiorum foi inoculada em folhas das melhores linhagens expressando RNAi correspondente a Sschs ( $L 3, L 4, L 5, L 6$ e L7) e também em cinco linhagens que não foi possível detectar Sschs-RNAi (L8, L9, L10, L13, L14 e não transgênica). O RNA total do fungo foi extraído 96 horas após a inoculação, para que os transcritos pudessem ser analisados (Figura 5). Além disso, RT-PCR semi-quantitativo foi realizado para demonstrar a especificidade dos primers utilizados em distinguir cDNA do fungo de um possível contaminante das plantas. $O$ fragmento de $95 \mathrm{pb}$ amplificado foi sequenciado, apresentando $100 \%$ de identidade ao gene Sschs. Não foi observado nenhum sinal nas plantas não inoculadas com o fungo, o que comprovou a especificidade dos primers aos genes do patógeno (Figura 5A). Os resultados demonstraram uma redução no nível de transcritos da quitina sintase endógena em S. sclerotiorum quando em interação com folhas de plantas transgênicas. Comparada ao controle, a redução variou de $46,7 \%$ a $61,5 \%$ (Figura 5B). A correlação entre o nível de expressão de Sschs e a área lesionada pode ser observada na Figura 5C. Estes resultados sugerem que os sinais de silenciamento translocados através do micélio de uma planta de tabaco transgênica para as células do fungo, suprimem parcialmente a expressão do gene da quitina sintase endógeno, comprometendo o desenvolvimento do fungo e infecção foliar. 


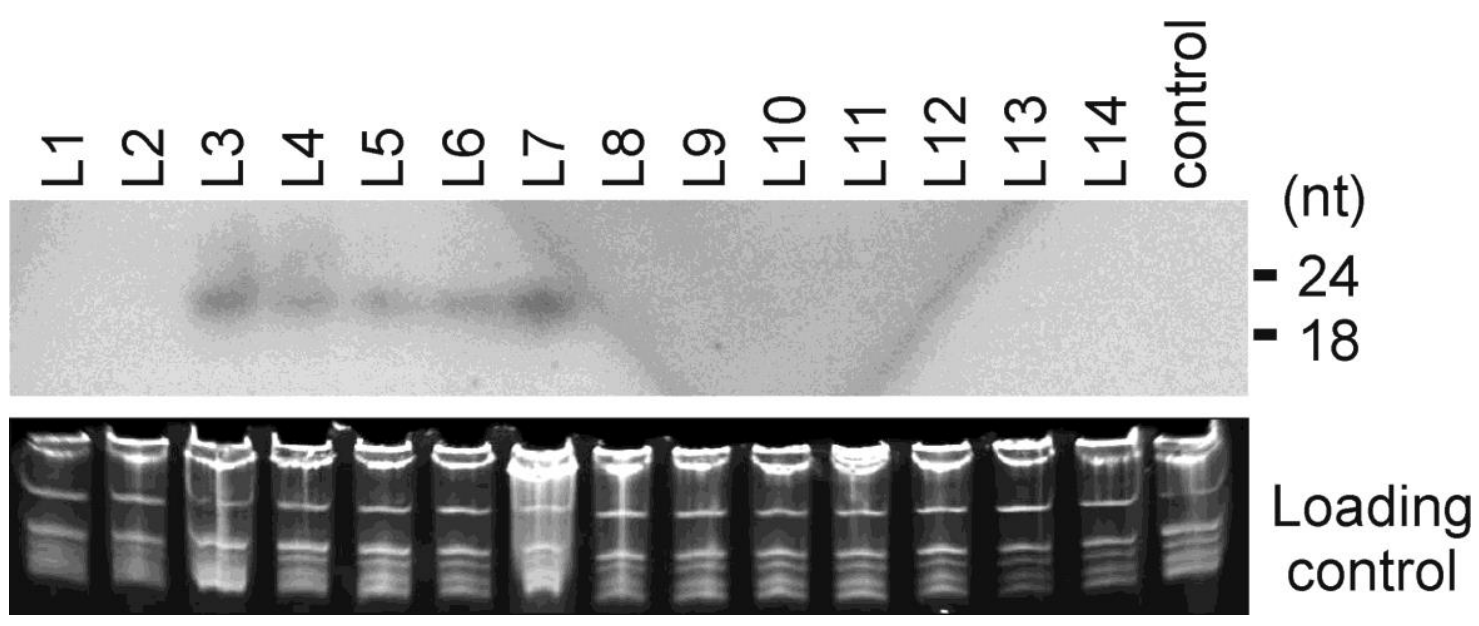

Figura 4. Análise de Northern Blot para detectar a presença de siRNA correspondente à sequencia chs em linhagens transgênicas e não transgênicas (controle). O gel de RNA corado com brometo de etídio serve como controle da corrida (abaixo). O marcador de tamanho molecular está indicado à direita.

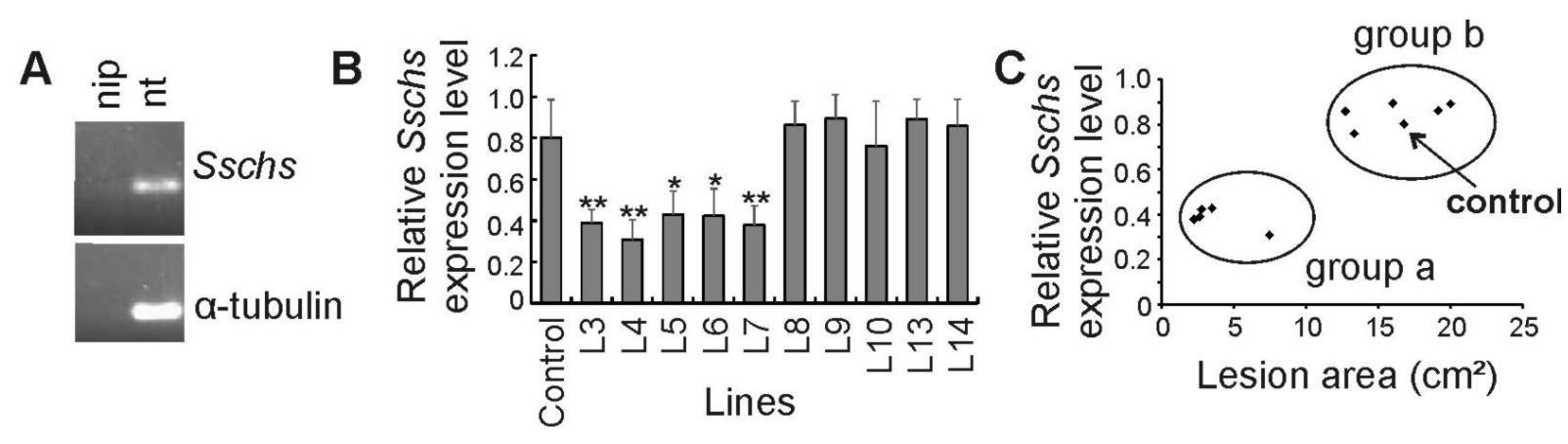

Figura 5. Expressão do gene chs em S. sclerotiorum infectando plantas transgênicas e não transgênicas (controle). (A) Análise de RT-PCR semi-quantitativo para detecção de transcritos de Sschs provenientes do crescimento do micélio em infecção em plantas não transgênicas (nt). Uma planta de fumo transgênica não inoculada com fungo (nip) também foi analisada para demonstrar a especificidade dos primers ao gene Sschs. (B) Expressão relativa de Sschs após 96h de inoculação em plantas não transgênicas (controle) e transgênicas (L3, L4, L5, L6, L7, L8, L9, L10, L13 e L14) determinada por PCR quantitativo em Tempo Real. Os dados representam a média de 3 replicações $( \pm S D)$. ${ }^{*} P<0.05 ;{ }^{* *} P<$ $0.01, n=9$, com relação ao controle. (C) Relação da expressão de Sschs e área lesionada nas linhagens transgênicas L3, L4, L5, L6 e L7 (grupo a) e L8, L9, L10, L13, L14 e controle (linhagem não transgênica apontada pela seta) (gurpo b). 


\section{Discussão}

A engenharia genética se firmou como uma importante ferramenta a ser utilizada em programas de melhoramento de plantas, contribuindo para o aumento de variabilidade genética, conseguindo a inserção de genes até então indisponíveis naquela cultura. Para obtenção de plantas resistentes a patógenos fúngicos, diversos são os trabalhos que demonstram essa possibilidade para o mofo branco. É o caso do trabalho de Cunha et al. (2010) que utilizando o gene oxdc, proveniente do fungo Flammulina velutipes, obteve plantas de soja com um certo nível de resistência à $S$. sclerotiorum. O gene introduzido codifica para a enzima oxalato descarboxilase, que degrada o ácido oxálico secretado por este fungo necrotrófico. Porém, uma recente e importante ferramenta de engenharia genética que surge é o RNAi, descortinando diversas possibilidades de obtenção de plantas resistentes a patógenos causadores de enormes danos às culturas, por meio do silenciamento gênico.

Em um trabalho anterior do nosso grupo de pesquisa foi reportado pela primeira vez que uma planta expressando dsRNA poderia gerar uma supressão no gene alvo correspondente em células fúngicas colonizando tecido foliar (Tinoco et al., 2010). Desde então, diversos trabalhos têm demonstrado o potencial biotecnológico deste tipo de abordagem para o desenvolvimento de plantas resistentes a fungos (Yin et al., 2011; Nunes e Dean, 2012; Panwar et al., 2013; Ghag et al., 2014; Govindarajulu et al., 2014). No entanto, as espécies de fungos em que o silenciamento gênico induzido pelo hospedeiro tem sido efetivo são patógenos biotróficos. Estes fungos estabelecem um longo período de alimentação com as células vivas do hospedeiro, porém não as matam. Por outro lado, é sugerido que parasitas hemi-biotróficos absorvem nutrientes de células hospedeiras em uma fase biotrófica precoce e só então as matam. Para os fungos biotróficos o longo período de alimentação que estabelecem com as células do hospedeiro, necessário para a absorção de nutrientes pelas células fúngicas, possibilita também a passagem das moléculas de dsRNA de seus hospedeiros para o parasita. Em contraste, patógenos necrotróficos matam as células de seus hospedeiros rapidamente, geralmente secretando toxinas, enzimas de degradação de parede celular de plantas e proteinases para causar/induzir a morte celular do hospedeiro (Zhu et al., 2013). 
Entretanto, evidências recentes sugerem uma forte interação entre patógenos necrotróficos e hospedeiros antes da morte de células e tecidos (Zhu et al., 2013; Kabbage et al., 2015). Até então acreditou-se que S. sclerotiorum é um típico fungo necrotrófico, tido como um patógeno agressivo que secreta grandes quantidades de ácido oxálico, associado a várias enzimas de degradação da parede celular que leva a morte de células e tecidos do hospedeiro (Kim et al., 2008). Por outro lado, análises recentes têm colocado Sclerotinia como um patógeno hemi-biotrófico com um estabelecimento fúngico anterior ao reconhecimento da planta, sendo mais temporal e espacialmente complexo do que observado anteriormente (Zhu et al., 2013; Kabbage et al., 2015).

No presente trabalho testamos a hipótese de que este curto período de interação entre o patógeno necrotrófico e as células vivas do tecido do hospedeiro poderia ser suficiente para mobilizar as moléculas de pequenos RNAs da planta para células fúngicas, gerando o silenciamento de genes do patógeno. Os resultados mostraram que linhagens transgênicas, nas quais os siRNAs correspondentes ao gene chs foram encontrados, apresentaram uma diferença significativa na área da lesão às $72 \mathrm{~h}$. A lesão não mostrou um extensivo progresso $120 \mathrm{~h}$ após a inoculação e mesmo um tempo maior que este, sugerindo que as células fúngicas quando em interação com as células vivas do hospedeiro tiveram seu desenvolvimento limitado, sendo progressivamente comprometido.

O fungo $S$. sclerotiorum é um patógeno muito agressivo e que se desenvolve rapidamente, porém houve um atraso entre a aquisição de moléculas de siRNA e o efeito de silenciamento gênico, resultando em sintomas tardios. Este fato confirma a hipótese que existe um estágio hemi-biotrófico em uma interação entre $S$. sclerotiorum com a planta, o que permite que moléculas de siRNA sejam absorvidas pelas células de alimentação do fungo e subsequentemente ocorra a interferência por RNA do gene Sschs.

O gene da quitina sintase foi escolhido devido ao fato de a quitina ser um importante componente de estruturas diferentes morfologicamente, sendo necessária durante diversas fases do crescimento e desenvolvimento. Ela é responsável pela rigidez da parede celular. A biossíntese de quitina é alvo de diversas drogas antifúngicas (Ruiz-Herrera e San-Blas, 2003; Bowman e Free, 2006), sendo um interessante alvo para obtenção de plantas resistentes via HIGS, por estar ausente em plantas, o que reduz a probabilidade que ocorra efeito 'off- 
target' devido a expressão do dsRNA correspondente ao gene chs. O gene chs 1 foi inativado em Neurospora crassa pela mutação pontual induzida repetida (Yarden e Yanofsky, 1991). Este fungo possui diversas quitina sintases, e a $N$. crassa mutada apresentou uma atividade residual de quitina sintase. No entanto, os mutantes produzidos apresentaram uma progênie de crescimento lento com hifas anormais morfologicamente, sendo este fenótipo relacionado a redução significativa da atividade da quitina sintase (Yarden e Yanofsky, 1991). Os mutantes simples $\triangle \mathrm{CHS} 5$ e $\triangle \mathrm{CHS7}$ e o duplo mutante $\Delta \mathrm{CHS} 5 / 7$ de $F$. verticillioides cresceram deficientemente e exibiram colônias pequenas, hiperpigmentadas e com pouco micélio quando comparadas ao tipo selvagem (Larson et al., 2011). Em Botrytis cinerea, um organismo modelo de patógeno necrotrófico, a ruptura do gene Bcchs1 reduziu a atividade da quitina sintase com a redução do conteúdo de quitina em $30 \%$, levando a um enfraquecimento da parede celular e pode retardar a progressão fúngica na planta (Soulié et al., 2003). A ruptura de Bcchs3a altera a adesão à célula do hospedeiro com a redução da virulência (Soulié et al., 2006; Arbelet et al., 2010). Deleções únicas de genes que codificam para diferentes $\mathrm{CHS}$ indicaram que BcCHS4 não é essencial para o desenvolvimento e patogenicidade de fungos, e BCCHS7 é necessário para patogenicidade em uma relação dependente de hospedeiro (Morcx et al., 2013). O genoma de S. sclerotiorum ainda não está totalmente descrito, porém no presente trabalho ficou demonstrado que o gene silenciado parece ser necessário para seu completo desenvolvimento, diminuindo assim sua patogenicidade, uma vez que a maquinaria do fungo não foi capaz de contornar este silenciamento. O fragmento do gene da quitina sintase CHS7 de F. verticilioides deve então estar associado ao desenvolvimento do fungo, pois assim como no trabalho de Larson et al. (2011) as colônias do fungo não se desenvolveram normalmente, in planta.

Muito ainda se tem a desvendar no processo de interação patógenohospedeiro, seus mecanismos e escapes. Porém com os recentes avanços biotecnológicos se percebe claramente que o melhoramento de plantas é uma ciência necessária para a manutenção da produção agrícola mundial. A combinação de diferentes metodologias (melhoramento clássico e transformação genética) e diversas técnicas (estaqueamento de genes, por exemplo) se apresenta como a melhor forma de se atingir este objetivo. 


\section{Conclusões}

Neste trabalho foi demonstrado que um gene endógeno do fungo necrotrófico bastante agressivo, S. sclerotiorum, pode ser silenciado através da passagem de siRNAs do hospedeiro transformado para o patógeno. HIGS para o gene da quitina sintase do fungo foi capaz de reduzir a infecção por ele gerada e, desta forma, foi possível gerar plantas de tabaco tolerantes ao mofo branco.

Do ponto de vista biotecnológico, nossos resultados abrem novas perspectivas para o desenvolvimento de plantas transgênicas resistentes a fungos patogênicos necrotróficos, que ainda estão entre os maiores desafios no melhoramento de plantas. A situação de mudanças climáticas, modificações na população dos patógenos e a resistência a fungicidas têm aumentado o imediatismo desta ação. 


\section{Considerações Finais e Perspectivas}

As doenças fúngicas estão, até os dias atuais, dentre os problemas que mais afligem produtores de todas as partes do planeta. Com o constante desenvolvimento de resistência a fungicidas e a necessidade de se realizar um controle eficaz, as ferramentas biotecnológicas surgem como um respiro para a continuidade de crescimento da produção agrícola. HIGS aparece neste contexto como um excelente candidato a ser amplamente utilizado para este fim. O progresso realizado com o sequenciamento de genomas de fungos e o entendimento da interação planta-fungo poderá ajudar a identificar genes alvos mais apropriados para patógenos necrotróficos.

Este trabalho demonstra a eficiência desta tecnologia em silenciar um gene fundamental de um fungo de grande importância para diversas culturas, causador de uma doença devastadora conhecida por mofo branco. Desta maneira, descortinamse diversas possibilidades de se utilizar da mesma tecnologia para obter cultivares de interesse econômico, como soja, feijão e tomate, entre outras, resistentes a esta doença que atualmente causa diversos prejuízos econômicos.

Cada dia mais aumenta a preocupação com o ambiente, com relação à intensa utilização de defensivos químicos e, mais uma vez HIGS do gene da quitina sintase de Sclerotinia sclerotiorum, demonstra ser uma importante e eficaz estratégia a ser utilizada, uma vez que reduziria o número de aplicações em diversas culturas. Somado a isso, HIGS tem a vantagem de selecionar um gene a ser silenciado específico ao organismo alvo, não sendo ativo no hospedeiro. Diante ao exposto, confirma-se a importância desta tecnologia ser introduzida em plantas de interesse, uma vez que ficou comprovado que a técnica foi efetiva e viável de ser conduzida. 


\section{Referências Bibliográficas}

ABDULLAH, M. T.; ALI, N.Y.; SULEMAN, P. Biological control of Sclerotinia sclerotiorum (Lib.) de Bary with Thrichoderma harzianum and Bacillus amyloliquefaciens. Crop Protection. v. 27, p. 1354-1359. 2008.

ALAKONYA, A.; KUMAR, R.; KOENIG, D.; KIMURA, S.; TOWNSLEY, B.; RUNO, S.; GARCES, H.M.; KANG, J.; YANEZ, A.; DAVID-SCHWARTZ, R.; MACHUKA, J.; SINHA, N. Interspecific RNA interference of SHOOT MERISTEMLESS-Like disrupts Cuscuta pentagona plant parasitism. Plant Cell. v. 24, p. 3153-3166. 2012.

AL-KAFF, N.S.; COVEY, S.N.; KREIKE, M.M.; PAGE, A.M.; PINDER, R.; DALE, P.J. Transcriptional and posttranscriptional plant gene silencing in response to a pathogen. Science. v. 279, p. 2113-2115. 1998.

ALY, R.; CHOLAKH, H.; JOEL, D.M.; LEIBMAN, D.; STEINITZ, B.; ZELCER, A.; NAGLIS, A.; YARDEN, O.; GAL-ON, A. Gene silencing of mannose 6-phosphate reductase in the parasitic weed Orobanche aegyptiaca through the production of homologous ds RNA sequences in the host plant. Plant Biotechnology Journal. v. 7, p. 487-498. 2009.

AMSELEM, J.; CUOMO, C.A.; KAN, J.A.L.; VIAUD, M.; BENITO, E.P.; COULOUX, A. et al. Genomic Analysis of the Necrotrophic Fungal Pathogens Sclerotinia sclerotiorum and Botrytis cinerea. Plos Genetics. v. 7, n. 8, e1002230. 2011.

ARANA, D.M.; PRIETO, D.; ROMÁN, E.; NOMBELA, C.; ALONSO-MONGE, R.; $\mathrm{PLA}, \mathrm{J}$. The role of the cell wall in fungal pathogenesis. Microbial Biotechnology. $\mathrm{v}$. 2, n. 3, p. 308-320. 2009.

ARAGÃO, F.J.L.; NOGUEIRA, E.O.P.L.; TINOCO, M.L.P.; FARIA, J.C. Molecular charaacterization of the first comercial transgenic common bean imune to the Bean golden mosaic virus. Journal of Biotechnology. v. 166, p. 42-50. 2013.

BAGO, B.; CHAMBERLAND, H.; GOULET, A.; VIERHEILIG, H.; LAFONTAINE, J.G.; PICHE, E. Effect of nikkomycin Z, a chitin synthase inhibitor, on hyphal growth and cell wall structure of two arbuscular-mycorrhizal fungi. Protoplasma. v. 192, p. 8092. 1996.

BALARDIN, R.S. Doenças do feijoeiro. In: Empresa de Pesquisa Agropecuária e Extensão Rural de Santa Catarina. A cultura do feijão em Santa Catarina. Florianópolis. 1992. p. 195-225.

BATEMAN, D.F.; BEER, S.V. Simultaneous production and synergistic action of oxalic acid and polygalacturonase during pathogenesis by Sclerotiorum rolfsii. Phytopathology. v. 55, p. 204-211. 1965.

BAULCOMBE, D. RNA silencing in plants. Nature, v. 431, p. 356-363, 2004. 
BAUM, J.A.; BOGAERT, T.; CLINTON, W.; HECK, G.R.; FELDMANN, P.; ILAGAN, O.; JOHNSON, S.; PLAETINCK, G.; MUNYIKWA, T.; PLEAU, M.; VAUGHN, T.; ROBERTS, J. Control of coleopteran insect pests through RNA interference. Nature Biotechnology. v. 25, p. 1322-1326. 2007.

BERNSTEIN, E.; CAUDY, A.A.; HAMMOND, S.M.; HANNON, G.J. Role for a bidentate ribonuclease in the initiation step of RNA interference. Nature. v. 409, p. 363-366. 2001.

BETTENCOURT, R.; TERENIUS, O.; FAYE, I. Hemolin gene silencing by ds-RNA injected into Cecropia pupae is lethal to next generation embryos. Insect Molecular Biology. v. 11, p. 267-271. 2002.

BOLAND, G. J.; HALL, R. Index of plant hosts of Sclerotinia sclerotiorum. Canadian Journal of Plant Pathology. v. 16, n. 2. 1994.

BOLTON, M. D.; THOMMA, B. P. H. J.; NELSON, B. D. Sclerotinia sclerotiorum (Lib.) de Bary: biology and molecular traits of a cosmopolitan pathogen. Molecular Plant Pathology. v. 7, n. 1, p. 1-16. 2006.

BONFIM, K.; FARIA, J. C.; NOGUEIRA, E. O.; MENDES, E. A.; ARAGÃO, F. J. L. RNAi-mediated resistance to Bean golden mosaic virus in genetically engineered common bean (Phaseolus vulgaris). Molecular Plant Microbe Interact. v. 20, p. 717-726, 2007.

BOTELHO, L. S.; ZANCAN, W. L. A.; MACHADO, J. C.; BARROCAS, E. N. Performance of common bean seeds infected by the fungus Sclerotinia sclerotiorum. Journal of Seed Science. v. 35, n. 2, p. 153-160. 2013.

BOWMAN, S.M.; FREE, S.J. The structure and synthesis of the fungal cell wall. Bioessays. v. 28, n. 8, p. 799-808. 2006.

BUCHER, G.; SCHOLTEN, J.; KLINGLER, M. Parental RNAi in Tribolium (Coleoptera). Current Biology. v. 12, p. R85-R86. 2002.

BUTT, A.; MOUSLEY, C.; MORRIS, K.; BEYNON, J.; CAN, C. et al. Differential expression of a senescence-enhanced metallothionein gene in Arabidopsis in response to isolates of Peronospora parasitica and Pseudomonas syringae. Plant Journal. v. 16, p. 209-221. 1998.

CARDOSO, J. E. Mofo branco. In: SARTORATO, A.; RAVA, C. A. Principais doenças do feijoeiro comum e seu controle. Brasília: EMBRAPA - SPI, 1994. p. 111-122. (Embrapa - CNPAF. Documentos, 50).

CESSNA, S.G.; SEARS, V.E.; DICKMAN, M.B.; LOW, P.S. Oxalic Acid, a Pathogenicity Factor for Sclerotinia sclerotiorum, Suppresses the Oxidative Burst of the Host Plant. The Plant Cell. v. 12, p. 2191-2199. 2000.

COLMENARES, A.J.; ALEU, J.; DURAN-PATRON, R.; COLLADO, I.G.; HERNANDEZ-GALAN, R. The putative role of botrydial and related metabolites in 
the infection mechanism of Botrytis cinerea. Journal of Chemical Ecology. v. 28, p. 997- 1005. 2002.

CUNHA, W. G.; TINOCO, M. L. P.; PANCOTI, H. L.; RIBEIRO, R. E.; ARAGÃO, F. J. L. High resistance to Sclerotinia sclerotiorum in transgenic soybean plants transformed to express na oxalate decarboxylase gene. Plant Pathology. v. 59, p. 654-660. 2010.

DIAS, B. B. A.; CUNHA, W. G.; MORAES, L. S.; VIANNA, G. R.; CAPDEVILLE, G. de; ARAGÃO, F. J. L. Expression of an oxalate decarboxylase gene from Flammulina sp. in transgenic lettuce (Lactuca sativa) plants and resistance to Sclerotinia sclerotiorum. Plant Pathology. v. 55, p. 187-193. 2006.

DISI, J. O.; MEI, J.; WEI, D.; DING, Y.; QIAN, W. Inheritance of leaf and stem resistance to Sclerotinia sclerotiorum in a cross between Brassica incana and Brassica oleracea var. alboglabra. Journal of Agricultural Science. v. 152, p. 146152. 2014.

DONALDSON, P. A.; ANDERSON, T.; LANE, B. G.; DAVIDSON, A. L.; SIMMONDS, D. H.; Soybean plants expressing an active oligomeric oxalate oxidase from the wheat gf-2.8 (germim) gene are resistant to the oxalate-secreting pathogen Sclerotinia sclerotiorum. Physiological and Molecular Plant Pathology. v. 59, p. 297-307. 2001.

DONG, X.; JI, R.; GUO, X.; FOSTER, S. J.; CHEN, H.; DONG, C.; LIU, Y.; HU, Q.; LIU, S. Expressing a gene encoding wheat oxalate oxidase enhances resistance to Sclerotinia sclerotiorum in oilseed rape (Brassica napus). Planta. v. 228, p. 331-340. 2008.

DUNOYER, P.; SCHOTT, G.; HIMBER, C.; MEYER, D.; TAKEDA, A.; CARRINGTON, J. C.; VOINNET, O. Small RNA duplexes function as mobile silencing signals between plant cells. Science. v. 328, p. 912-916. 2010.

ECKARDT, N. A. Chitin Signaling in Plants: Insights into the Perception of Fungal Pathogens and Rhizobacterial Symbionts. The plant cell. v. 20, p. 241-243. 2008.

EDWARDS, K.; JOHNSTONE, C.; THOMPSON, C. A simple and rapid method for the preparation of plant genomic DNA for PCR analysis. Nucleic Acids Research. $v$. 19, n. 6, p. 1349. 1991.

ESCOBAR, M.A.; CIVEROLO, E.L.; SUMMERFELT, K.R.; DANDEKAR, A.M. RNAimediated oncogene silencing confers resistance to crown gall tumorigenesis. PNAS. v. 98, p. $13437-13442.2001$.

FAIRBAIRN, D. J.; CAVALLARO, A. S.; BERNARD, M.; MAHALINGA-IYER, J.; GRAHAM, M.W.; BOTELLA, J. R. Host-delivered RNAi: an effective strategy to silence genes in plant parasitic nematodes. Planta. v. 226, p. 1525-1533. 2007. 
FAVARON, F.; SELLA, L.; D'OVIDIO, R. Relationships among endopolygalacturonase, oxalate, $\mathrm{pH}$, and plant polygalacturonase-inhibiting protein (PGIP) in the interaction between Sclerotinia sclerotiorum and soybean. Molecular Plant-Microbe Interactions. v. 17, p. 1402-1409. 2004.

FIGUEIRÊDO, G. S. D.; FIGUEIRÊDO, L. C. D.; CAVALCANTI, F. C. N. SANTOS, A. C. D.; COSTA, A.F.D.; OLIVEIRA, N.T.D. Biological and chemical control of Sclerotinia sclerotiorum using Trichoderma spp. and Ulocladium atrum and pathogenic to bean plants. Brazilian Archives of Biology and Technology. v. 53, n. 1, p. 1-9. 2010.

FILHO, A. B.; KIMATI, H. Importância das doenças de plantas. In: FILHO, A. B.; KIMATI, H.; AMORIM, L. Manual de Fitopatologia. 3 ed. São Paulo: Agronômica Ceres, 1995. v.1, cap. 2, p.13-19.

FIRE, A.; XU, S.; MONTGOMERY, M.K.; KOSTAS, S.A.; DRIVER, S.E.; MELLO, C.C. Potent and specific genetic interference by double-stranded RNA in Caenorhabditis elegans. Nature. v. 391, p. 806-811. 1998.

FIRE, A.Z. Gene silencing by double-stranded RNA (Nobel lecture). Cell Death and Differentiation. v. 14, p. 1998-2012. 2007.

GERALDINE, A. M.; LOPES, F. A. C.; CARVALHO, D. D. C.; BARBOSA, E. T.; RODRIGUES, A. R.; BRANDÃO, R. S.; ULHOA, C. J.; LOBO JÚNIOR, M. Cell walldegrading enzymes and parasitism of sclerotia are key factors on field biocontrol of white mold by Trichoderma spp. Biological Control. v. 67, p. 308-316. 2013.

GHAG, S. B.; SHEKHAWAT, U. K. S.; GANAPATHI, T. R. Host-induced posttranscriptional hairpin RNA-mediated gene silencing of vital fungal genes confers efficient resistance against Fusarium wilt in banana. Plant Biotechnology Journal. v. 12 , p. 541-553. 2014.

GHEYSEN, G.; VANHOLME, B. RNAi from plants to nematodes. Trends in Biotechnology. v. 25, p. 89-92. 2007.

GHILDIYAL, M.; ZAMORE, P.D. Small silencing RNAs: an expanding universe. Nature Reviews Genetics. v. 10, n. 2, p. 94-108. 2009.

GLAZEBROOK, J. Contrasting mechanisms of defense against biotrophic and necrotrophic pathogens. Annual Review of Phytopathology. v. 43, p. 205-227. 2005.

GODOY, G.; STEADMAN, J.R.; DICKMAN, M.B.; DAM, R. Use of mutants to demonstrate the role of oxalic acid in pathogenicity of Sclerotinia sclerotiorum on Phaseolus vulgaris. Physiological and Molecular Plant Pathology. v. 37, p. 179191. 1990. 
GOSSEN, B.D., RIMMER, S.R.; HOLLEY, J.D. First report of resistance to benomyl fungicide in Sclerotinia sclerotiorum. Plant Disease. v. 85, p. 1206. 2001.

GOVINDARAJULU, M.; EPSTEIN, L.; WROBLEWSKI, T.; MICHELMORE, R. W. Host-induced gene Silencing inhibits the biotrophic pathogen causing downy mildew of lettuce. Plant Biotechnology Journal. p. 1-9. 2014.

GUIMARAES, R.L.; STOTZ, H.U. Oxalate production by Sclerotinia sclerotiorum deregulates guard cells during infection. Plant Physiology. v. 136, p. 3703-3711. 2004.

HEGEDUS, D. D.; RIMMER, S. R. Sclerotinia sclerotiorum: When "to be or not to be" a pathogen? FEMS Microbiology Letters. v. 251, p. 177-184. 2005.

HORBACH, R.; NAVARRO-QUESADAC, A. R.; KNOGGE, W.; DEISING, B. When and how to kill a plant cell: Infection strategies of plant pathogenic fungi. Journal of Plant Physiology. v. 168, p. 51-62. 2011.

HORCH, R. B.; FRY, J. E.; HOFFMANN, N. L.; WALLROTH, M.; EICHHOLTZ, D.; ROGERS, S. G.; FRALEY, R. T. A simple and general method for transferring genes into plants. Science. v. 227, p. 1229-1231. 1985.

HU X.; BIDNEY, D. L.; YALPANI, N.; DUVICK, J. P.; CRASTA, O.; FOLKERTS, O.; $\mathrm{LU}, \mathrm{G}$. Overexpression of a gene encoding hydrogen peroxide-generating oxalate oxidase evokes defense responses in sunflower. Plant Physiology. v. 133, p. 170181. 2003.

HUANG, H. C.; DUECK, J. Wilt of sunflower from infection by mycelial-germinating sclerotia of Sclerotinia sclerotiorum. Canadian Journal of Plant Pathology. v. 2, n. 2, p. 47-52. 1980.

HUANG, G.Z.; ALLEN, R.; DAVIS, E.L.; BAUM, T.J.; HUSSEY, R.S. Engineering broad root-knot resistance in transgenic plants by RNAi silencing of a conserved and essential root-knot nematode parasitism gene. Proceedings of the National Academy of Sciences, USA. v. 103, p. 14302-14306. 2006.

IBRAHIM, H.M.M.; ALKHAROUF, N.W.; MEYER, S.L.F.; ALY, M.A.M; GAMAL ELDIN, A.Y.; HUSSEIN, E.H.A.; MATTHEWS, B.F. Post-transcriptional gene silencing of root-knot nematode in transformed soybean roots. Experimental Parasitology. v. 127, p. 90-99. 2011.

IBRAHIM, A.B. Resistência à mosca branca (Bemisia tabaci) em plantas transgênicas expressando siRNA de uma v-ATPase. 2015. 81p. Tese (Doutorado em Biologia Molecular) - Universidade de Brasília, Brasília.

JEFFERSON, R.A.; KAVANAGH, T.A.; BEVAN, M.W. GUS fusions: betaglucuronidase as a sensitive and versatile gene fusion marker in higher plants. The EMBO Journal. v. 6, p. 3901-3907. 1987. 
JINEK, M.; DOUDNA, J.A. A three-dimensional view of the molecular machinery of RNA interference. Nature. v. 457, p. 405-412. 2009.

KABBAGE, M.; YARDEN, O.; DICKMAN, M.B. Pathogenic attributes of Sclerotinia sclerotiorum: switching from a biotrophic to necrotrophic lifestyle. Plant Science. v. 233, p. 53-60. 2015.

KABIR, M.H.; QADIR, S.A.; HASSAN, S.H.A.; AHN, J.; WANG, M-H. RNAi: An emerging field of molecular research. African Journal of Biotechnology. v. 7, n. 25, p. 4784-4788. 2008.

KAMATH, R.S.; AHRINGER, J. Genome-wide RNAi screening in Caenorhabditis elegans. Methods. v. 30, p. 313-321. 2003.

KESARWANI, M.; AZAM, M.; NATARAJAN, K.; MEHTA, A.; DATTA, A. Oxalate decarboxylase from Collybia velutipes. The Journal of Biological Chemistry. v. 275, n. 10, p. 7230-7238. 2000.

KIM, H. S.; DIERS, B. W. Inheritance of partial resistance to Sclerotinia stem rot in soybean. Crop Science. v. 40, p. 55-61. 2000.

KIM, K.S.; MIN, J-Y.; DICKMAN, M.B. Oxalic acid is an elicitor of plant programmed cell death during Sclerotinia sclerotiorum disease development. Molecular PlantMicrobe Interactions. v. 21, p. 605-612. 2008.

KIMATI, H. Doenças do feijoeiro. In: GALLI, F. Manual de fitopatologia. 2 ed. São Paulo: Agronômica Ceres, 1980. v. 2, p. 297-318.

KLIEBENSTEIN, D.J.; ROWE, H.C. Ecological costs of biotrophic versus necrotrophic pathogen resistance, the hypersensitive response and signal transduction. Plant Science. v. 174, p. 551-556. 2008.

$\mathrm{KOCH}, \mathrm{A}$.; KOGEL, K.H. New wind in the sails: improving the agronomic value of crop plants through RNAi-mediated gene silencing. Plant Biotechnology Journal. v. 12, p. 821-831. 2014.

KUNKEL, B.N.; BROOKS, D.M. Cross talk between signaling pathways in pathogen defense. Current Opinion Plant Biology. v. 5, p. 325-31. 2002.

LARSON, T.M.; KENDRA, D.F.; BUSMAN, M.; BROWN, D.W. Fusarium verticillioides chitin synthases CHS5 and $\mathrm{CHS7}$ are required for normal growth and pathogenicity. Current genetics. v. 57, p. 177-189. 2011.

LEE, J-Y;CUI, W. Non-cell autonomous RNA trafficking and long-distance signaling. Journal of Plant Biology. v. 52, p. 10-18. 2009. 
LEONARDON, M. D.; MUNRO, C. A.; GOW, N. A. R. Chitin synthesis and fungal pathogenesis. Current Opinion in Microbiology. v. 13, p. 416-423. 2010.

LINDBO, J.A.; DOUGHERTY, W.G. Untranslatable transcripts of the tobacco etch virus coat protein gene sequence can interfere with tobacco etch virus replication in transgenic plants and protoplasts. Virology. v. 189, p. 725-733. 1992.

LILLEY, C. J.; DAVIES, L. J.; URWIN, P. E. RNA interference in plant parasitic nematodes: a summary of the current status. Parasitology. v. 139, 630-640. 2012.

LIVAK, K.J.; SCHMITTGEN, T.D. Analysis of relative gene expression data using real-time quantitative PCR and the $2^{\Delta \Delta} \mathrm{C}(\mathrm{T})$ Method. Methods. v. 25, p. 402-408. 2001.

LIVINGSTONE, D. M.; HAMPTON, J. L.; PHIPPS, P. M.; GRABAU, E. A. Enhancing resistance to Sclerotinia minor in peanut by expressing a barley oxalate oxidase gene. Plant Physiology. v. 137, p. 1354-1362. 2005.

MARTÍN-UDÍROZ, M.; MADRID, M. P.; RONCERO, M. I. G. Role of chitin synthase genes in Fusarium oxysporum. Microbiology. v. 150, p. 3175-3187. 2004.

MELNYK, C.W.; MOLNAR, A.; BAULCOMBE, D.C. Intercellular and systemic movement of RNA silencing signals. The EMBO Journal. v. 30, p. 3553-3563. 2011.

MENDGEN, K.; HAHN, M. Plant infection and the establishment of fungal biotrophy. Trends in Plant Science. v. 7, n. 8, p. 352-356. 2002.

MENEZES, J. R. Controle integrado das doenças do feijoeiro comum irrigado por pivô central. Summa Phytopathologica. v. 21, n. 1, p. 65-66. 1995.

MEYER, V. Genetic engineering of filamentous fungi - Progress, obstacles and future trends. Biotechnology Advances. v. 26, p. 177-185. 2008.

MIKLAS, P. N.; GRAFTON, K. F. Inheritance of partial resistance to white mold in inbreed populations of dry bean. Crop Science. v. 32, n. 4, p. 943-948. 1992.

MIKLAS, P. N.; PORTER, L. D.; KELLY, J. D.; MYERS, J. R. Characterization of white mold disease avoidance in common bean. European Journal of Plant Pathology. Jan. 2013.

MOLNAR, A.; MELNYK, C. W.; BASSETT, A.; HARDCASTLE, T. J.; DUNN, R.; BAULCOMBE, D. C. Small silencing RNAs in plants are mobile and direct epigenetic modification in recipient cells. Science. v. 328, p. 872-875. 2010.

MORCX, S.; KUNZ, C.; CHOQUER, M.; ASSIE, S.; BLONDET, E.; SIMOND-COTE, E.; GAJEK, K.; CHAPELAND-LECLERC, F.; EXPERT, D.; SOULIÉ, M.C. Disruption of Bcchs4, Bcchs6 or Bcchs7 chitin synthase genes in Botrytis cinerea and the essential role of class $\mathrm{VI}$ chitin synthase (Bcchs6). Fungal genetics and biology. $\mathrm{V}$. 52, p. 1-8. 2013. 
MOREL, J.B.; GODON, C.; MOURRAIN, P.; BÉCLIN, C.; BOUTET, S.; FEUERBACH, F.; PROUX, F.; VAUCHERET, H. Fertile hypomorphic ARGONAUTE (ago1) mutants impaired in post-transcriptional gene silencing and virus resistance. The Plant Cell. v. 14, n. 3, p. 629-639. 2002.

MUELLER, D. S.; HARTMAN, G. L.; PEDERSEN, W. L. Development of sclerotia and apothecia of Sclerotinia sclerotiorum from infected soybean seed and its control by fungicide seed treatment. Plant Disease. v. 83, n. 12, p. 1113-1115. 1999.

NAKAYASHIKI, H. RNA silencing in fungi: Mechanisms and applications. FEBS Letters. v. 579, p. 5950-5957. 2005.

NOWARA, D.; GAY, A.; LACOMME, C.; SHAW, J.; RIDOUT, C.; DOUCHKOV, D.; HENZEL, G.; KUMLEHN, J.; SCHWEIZER, P. HIGS: host-induced gene silencing in the obligate biotrophic fungal pathogen Blumeria graminis. The Plant Cell Online. v. 22, p. 3130-3141, 2010.

NUNES, C. C.; DEAN, R. A. Host-induced gene silence: a tool for understanding fungal host interaction and for developing novel disease control strategies. Molecular Plant Pathology. v. 13, n. 5, p. 519-529. 2012.

OLIVEIRA, J. A. P.; MORAES, E. R.; TEIXEIRA, I. R.; MOTA, J. H.; COELHO, M.; SILVA, A. G.; LÔBO JÚNIOR, M. Yield quality of common bean seeds in response to management tactics against white mold disease. American-Eurosian Journal Agric. \& Environ. Science. v. 15, n. 2, p. 251-258. 2015.

PANWAR, V.; MCCALLUM, B.; BAKKEREN, G. Host-induced gene silencing of wheat leaf rust fungus Puccinia triticina pathogenicity genes mediated by the Barley stripe mosaic virus. Plant Molecular Biology. v. 81, p. 595-608. 2013.

PEDERSEN, P.; LAUER, J.G. Soybean growth and development in various management systems and planting dates. Crop Sciences. v. 44, n. 2, p. 508-515. 2004.

PELTIER, A. J.; BRADLEY, C. A.; CHILVERS, M. I.; MALVICK, D. K.; MUELLER, D. S.; WISE, K. A.; ESKER, P.D. Biology, yield loss and control of Sclerotinia Stem Rot of soybean. Journal os Integrated Pest Management. v. 3, n. 2, p. 1-7. 2012.

PRATT, R. G.; ROWE, D. E.; Differencial responses of alfafa genotypes to stem inoculations with Sclerotinia sclerotiorum and S. trifolium. Plant Disease. v. 75, n. 2, p. 188-191. 1991.

PURDY, L. H. Sclerotinia sclerotiorum: history, disease and symptomology host range, geographic distribuition and impact. Phytopathology. v. 69, n. 8, p. 875-880. 1979.

RIBEIRO, S. G. S. P. Tratamento de sementes de soja para controle de Sclerotinia sclerotiorum. 2010. 28p. Monografia (Pós-Graduação em Fitopatologia) - Universidade Federal de Lavras. 
RHOADES, M.W.; REINHART, B.J.; LIM, L.P.; BURGE, C.B.; BARTEL, B.; BARTEL, D.P. Prediction of plant microRNA targets. Cell. v. 110, p. 513-520. 2000.

RONCERO, C. The genetic complexity of chitin synthesis in fungi. Current Genetics. v. 41 , p. 367-378. 2002.

RUIZ-HERRERA, J.; SAN-BLAS, G. Chitin synthesis as a target for antifungal drugs. Current Drug Targets-Infectious Disorders. v. 3, p. 77-91. 2003.

SANITT, P.; ATTASART, P.; PANYIM, S. Protection of yellow head virus infection in shrimp by feeding of bacteria expressing dsRNAs. Journal of biotechnology, v.179, p. 26-31, 2014.

SCHWARTZ, H. F.; SINGH, S. P. Breeding common bean for resistance to white mold: a review. Crop Science. v. 53, p. 1832-1844. 2013.

SCOTT, A.J.; KNOTT, M. Cluster analysis method for grouping means in the analysis of variance. Biometrics. v. 30, p. 507-512. 1974.

SINGH, N.; MUKHERJEE, S.; MANCHIKATLA, R. Host induced RNAi-mediated silencing of the ornithine decarboxylase gene of Fusarium oxysporum $\mathrm{f}$. $\mathrm{sp}$. lycopersici confers resistance to Fusarium wilt in tomato. Plant Biotechnology Journal, 2014.

SIOMI, H.; SIOMI, M. C. On the road to reading the RNA-interference code. Nature, v. 457, p. 369-404, 2009.

SOLER, N.; PLOMER, M.; FAGOAGA, C.; MORENO, P.; NAVARRO, L.; FLORES, R.; PEÑA, L. Transformation of Mexican lime with an intron-hairpin construct expressing untranslatable versions of the genes coding for the three silencing suppressors of Citrus tristeza virus confers complete resistance to the virus. Plant Biotechnology Journal. v. 10, p. 597-608. 2012.

SPECHT, C.A.; LIU, Y.; ROBBINS, P.W.; BULAWA, C.E.; IARTCHOUK, N.; BORGIA, P.T. The chsD and chsE genes of Aspergillus nidulans and their roles in chitin synthesis. Fungal Genetics Biology. v. 20, p. 153-167. 1996.

STEADMAN, J. R. White mold: a serious yield limiting disease of bean. Plant Disease. v. 67, n. 4, p. 346-350. 1983.

STEADMAN, J. R.; BOLAND, G. White mold. In: SCHWARTZ, H.F.; STEADMAN, J. R.; HALL, R.; FORSTER, R. L. Compendium of bean diseases. 2 ed. Am. Phytopath. Soc., St. Paul, 2005. p. 44-46.

STEEL, R.G.D.; TORRIE, J.H. Principles and Procedures of Statistics. New York, USA: McGraw-Hill. 1980. 
SUN, P.; YANG, X. B. Light, tempeture, and moisture effects on apothecium production. Plant Disease. v. 84, n. 12, p. 1287-1293. 2000.

TEIXEIRA, I.R.; CARVALHO, L.R.; REIS, E.F.; SILVA, A.G.; TEIXEIRA, G.C.S. The Effectiveness of Interaction Between Chemical Fungicides, Bio-Agent and Plant Densities on the White Mold Disease in the Common Bean. Journal of Agricultural Science. v. 5, n. 7, p. 255-261. 2013.

THALER, J.S.; OWEN, B.; HIGGINS, V.J. The role of the jasmonate response in plant susceptibility to diverse pathogens with a range of lifestyles. Plant Physiology. v. 135 , p. $530-538.2004$.

THOMMA, B.P.; EGGERMONT, K.; PENNINCKX, I.A.M.A.; MAUCH-MANI, B.; VOGELSANG R.; CAMMUE, B.P.A.; BROEKAERT, W.F. Separate jasmonatedependent and salicylate-dependent defense response pathways in Arabidopsis are essential for resistance to distinct microbial pathogens. PNAS. v. 95, p. 1510715111. 1998.

TINOCO, M. L. P.; DIAS, B. B. A.; DALL'ASTTA, R. C.; PAMPHILE, J. A.; ARAGÃO, F. J. L. In vivo trans-specific gene silencing in fungal cells by in planta expression of a double-strand RNA. BMC Biology. v. 8, n. 27. 2010.

TOMILOV, A. A.; TOMILOVA, N. B.; WROBLEWSKI, T.; MICHELMORE, R.; YODER, J. I. Trans-specific gene silencing between host and parasitic plants. The Plant Journal. v. 56, p. 389-397. 2008.

URWIN, P.E.; LILLEY, C.J.; ATKINSON, H.J. Ingestion of double-stranded RNA by preparasitic juvenile cyst nematodes leads to RNA interference. Molecular PlantMicrobe Interactions. v. 15, p. 747-752. 2002.

VALE, F. X. R.; FILHO, E. I. F.; LIBERATO, J. R. QUANT. A software for plant disease severity assessment. In: $\mathbf{8}^{\text {th }}$ International Congress of Plant Pathology. Christchurch, New Zealand: 105. 2003.

VIEIRA, R. F. Mofo branco no feijoeiro. Informe Agropecuário. Belo Horizonte, v. 17, n. 178, p. 54-63. 1994.

VUONG, T. D.; DIERS, B. W.; HARTMAN, G. L. Identification of QTL for resistance to Sclerotinia stem rot in soybean plant introduction 194639. Crop Science. v. 48, p. 2209-2214. 2008.

WALZ, A.; ZINGEN-SELL, I.; LOEFFLER, M.; SAUER, M. Expression of an oxalate oxidase gene in tomato and severity of disease caused by Botrytis cinerea and Sclerotinia sclerotiorum. Plant Pathology. v. 57, p. 453-458. 2008.

WANG, M.B.; ABBOTT, D.C.; WATERHOUSE, P.M. A single copy of a virus-derived transgene encoding hairpin RNA gives immunity to barley yellow dwarf virus. Molecular plant pathology. v. 1, n. 6, p. 347-356. 2000. 
WATERHOUSE, P.M.; GRAHAM, M.W.; WANG, M.B. Virus resistance and gene silencing in plants can be induced by simultaneous expression of sense and antisense RNA. Proceedings of the National Academy of Sciences. v. 95, p. 13959-13964. 1998.

WEIBERG, A.; WANG, M.; LIN, F.M.; ZHAO, H.; ZHANG, Z.; KALOSHIAN, I.; HUANG, H.D.; JIN, H. Fungal Small RNAs Suppress Plant Immunity by Hijacking Host RNA Interference Pathways. Science. v. 342, p. 118-123. 2013.

WEIBERG, A.; BELLINGER, M.; JIN, H. Conversations between kingdoms: small RNAs. Current Opinion in Biotechnology. v. 32, p. 207-215. 2015.

WHIPPS, J.M.; BUDGE, S.P. Screening for sclerotial mycoparasites of Sclerotinia sclerotiorum. Mycological Research. v. 4, p. 607-612. 1990.

YARDEN, O.; YANOFSKY, C. Chitin synthase 1 plays a major role in cell wall biogenesis in Neurospora crassa. Genes \& Development. v. 5, p. 2420-2430. 1991.

YIN, C.; JURGENSON, J. E.; HULBERT, S. H. Development of a host-induced RNAi system in the wheat stripe rust fungus Puccinia striiformis f. sp. tritici. Molecular Plant-Microbe Interactions. v. 24, n. 5, p. 554-561. 2011.

ZHANG, H.; LI, H. C.; MIAO, X. X. Feasibility, limitation and possible solutions of RNAi-based technology for insect pest control. Insect Science. v. 20, p. 15-30. 2013.

ZHU W., WEI W., YANPING F., CHENG J., XIE J., LI G., YI X., KANG Z., DICKMAN M.B., JIANG D. A secretory protein of necrotrophic fungus Sclerotinia sclerotiorum that suppresses host resistance. Plos One. v. 8, e53901. 2013. 
Anexo 


\title{
Host-induced gene silencing in the necrotrophic fungal pathogen Sclerotinia sclerotiorum
}

\author{
C. M. Andrade ${ }^{a b}$, M. L. P. Tinoco ${ }^{a}$, A. F. Rieth ${ }^{a}$, F. C. O. Maia ${ }^{a}$ and F. J. L. Aragão ${ }^{a *}$

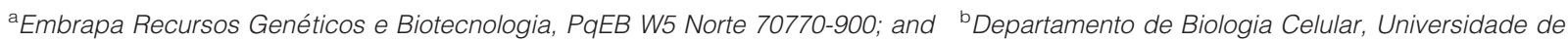 \\ Brasília, Campus Universitário, 70910-900 Brasília, DF, Brazil
}

Sclerotinia sclerotiorum is a necrotrophic fungus that causes a devastating disease called white mould, infecting more than 450 plant species worldwide. Control of this disease with fungicides is limited, so host plant resistance is the preferred alternative for disease management. However, due to the nature of the disease, breeding programmes have had limited success. A potential alternative to developing necrotrophic fungal resistance is the use of host-induced gene silencing (HIGS) methods, which involves host expression of dsRNA-generating constructs directed against genes in the pathogen. In this study, the target gene chosen was chitin synthase (chs), which commands the synthesis of chitin, the polysaccharide that is a crucial structural component of the cell walls of many fungi. Tobacco plants were transformed with an interfering intron-containing hairpin RNA construct for silencing the fungal chs gene. Seventy-two hours after inoculation, five transgenic lines showed a reduction in disease severity ranging from 55.5 to $86.7 \%$ compared with the non-transgenic lines. The lesion area did not show extensive progress over this time (up to $120 \mathrm{~h}$ ). Disease resistance and silencing of the fungal chs gene was positively correlated with the presence of detectable siRNA in the transgenic lines. It was demonstrated that expression of endogenous genes from the very aggressive necrotrophic fungus S. sclerotiorum could be prevented by host induced silencing. HIGS of the fungal chitin synthase gene can generate white mould-tolerant plants. From a biotechnological perspective, these results open new prospects for the development of transgenic plants resistant to necrotrophic fungal pathogens.

Keywords: fungus resistance, gene silencing, HIGS, Sclerotinia sclerotiorum, white mould

\section{Introduction}

Sclerotinia sclerotiorum is a necrotrophic ascomycete fungus that causes a worldwide and devastating disease called white mould. The fungus infects more than 450 plant species, including important crops such as canola, potato, cotton, tomato, sunflower, common bean and soybean (Bolton et al., 2006).

Effective control of white mould with fungicides is difficult due to low penetration and uneven distribution (Schwartz \& Singh, 2013). Additionally, the use of fungicides increases production costs and has environmental impacts. Therefore, fungicide control should be combined with disease management based on good agronomic practices, such as planting under tillage, use of lodging resistant varieties, wide-row planting, and rotation with non-host crops, irrigation water management and biological control. In favourable environmental conditions for pathogen development, these practices are not sufficient to control disease. In addition, the fungus is seed-transmitted and produces sclerotia (hardened dense mycelial bodies) that survive in soil for years, awaiting the appropriate conditions for germination (Schwartz \& Steadman, 1989). Thus, use of adequate levels of host

*E-mail: francisco.aragao@embrapa.br plant resistance is the best alternative for white mould management (Disi et al., 2014). Due to the nature of the disease, breeding programmes have had limited success. Genetic resistance to $S$. sclerotiorum is complex, has low heritability and is restricted to a few lines that have shown only partial resistance (Disi et al., 2014). In addition, the plant escape mechanisms and environmental conditions make white mould resistance evaluations difficult in the field. It may be difficult to discriminate between physiological resistance and plant architectural disease avoidance because these are easily confused under field conditions (Miklas \& Grafton, 1992).

A potential alternative to developing white mouldresistant plants is the development of genetic engineering strategies by expressing or silencing genes involved in plant-Sclerotinia interactions. The main strategy used so far consists of the expression of genes encoding enzymes capable of degrading oxalic acid, such as oxalate oxidases and oxalate decarboxylases, which have produced enhanced resistance to S. sclerotiorum (Kesarwani et al., 2000; Hu et al., 2003; Dias et al., 2006; Dong et al., 2008; Cunha et al., 2010). Another alternative is the use of host-induced gene silencing (HIGS) methods, which exploit the silencing effect of small interfering RNA (siRNA) signals in interacting organisms, and involves host expression of siRNA-generating constructs directed against genes in associated pathogens, parasites 
or symbionts (Knip et al., 2014). It has been demonstrated that large and small RNA molecules are mobile within organisms, and several cases in which RNAsilencing signals travel between different organisms have been described (Kim et al., 2014; for a review see Nunes \& Dean, 2012). Cross-species transfer of RNAsilencing signals have been reported from plants to pathogenic and symbiotic microbes, from plants to nematodes (Lilley et al., 2012), from fungal pathogens to plants (Nunes \& Dean, 2012), and from plants to insects (Zhang et al., 2013). Tinoco et al. (2010) demonstrated, for the first time, the in vivo interference phenomenon in the pathogenic fungus Fusarium verticillioides, by inoculating mycelial cells into transgenic tobacco plants engineered to express siRNAs from a dsRNA corresponding to a particular fungal transgene, so specifically abolishing expression of that transgene. HIGS strategies are now being explored to obtain stable and transient expression of siRNA transgenes in order to achieve resistance to biotrophic fungi, such as Blumeria graminis in barley and wheat (Nowara et al., 2010), Puccinia striiformis in wheat (Yin et al., 2011), Puccinia triticina in wheat (Panwar et al., 2013), Fusarium oxysporum in banana (Ghag et al., 2014) and Bremia lactucae in lettuce (Govindarajulu et al., 2015).

The examples of HIGS reported so far corroborate the hypothesis that small RNA molecules are able to move from plants into fungal cells and effectively silence their target genes. Nevertheless, the pathogenic fungi tested so far have a long-term biotrophic phase, establishing conditions for a longer feeding relationship with a living host plant cell, allowing the nutrient-absorbing cells to take up double-stranded RNA molecules from their host. The aim of the present study was to investigate whether HIGS could be used to silence an endogenous gene in $S$. sclerotiorum, a necrotrophic plant pathogen, in which the virulence process proceeds faster to the transition from the initial symptomless phase to the necrotrophic phase. The target gene chosen was chitin synthase (chs), which commands the synthesis of chitin, the polysaccharide that is a crucial structural component of the cell walls of many fungi.

\section{Materials and methods}

\section{RNAi construct and plant transformation}

A fragment containing a partial sequence from the chs coding sequence from $F$. verticillioides was amplified by PCR. Primer pair ChirnaiF (5'-AGGGCCCGGTACCTTCAGCGTATGCC-3') and ChirnaiR ( $5^{\prime}$-A GAGCTCTCTAGAGGCCAATCGAGGG-3')

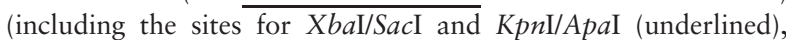
respectively) was used to amplify a $494 \mathrm{bp}$ fragment (position 624-1117 in the GenBank accession number GU066261.1) from the chs gene. The F. verticillioides gene has $67 \%$ similarity with the $S$. sclerotiorum chitin synthase gene (Sschs) (GenBank accession number XM_001584969.1). PCR reactions were carried out in a thermocycler (MyCycler; Bio-Rad) in a $50 \mu \mathrm{L}$ solution containing $40 \mathrm{ng}$ cDNA, $60 \mathrm{~mm} \mathrm{Tris}_{-} \mathrm{SO}_{4}(\mathrm{pH}$ 8.9), $18 \mathrm{~mm}$ $\left(\mathrm{NH}_{4}\right)_{2} \mathrm{SO}_{4}, 2 \mathrm{~mm} \mathrm{MgSO}$, $250 \mathrm{~nm}$ each dNTP, $200 \mathrm{~nm}$ each primer, and $5 \mathrm{U}$ Platinum Taq DNA polymerase (Invitrogen). The mixture was treated at $94^{\circ} \mathrm{C}(1 \mathrm{~min})$ and subjected to 40 cycles of amplification $\left(94^{\circ} \mathrm{C}\right.$ for $1 \mathrm{~min}, 60^{\circ} \mathrm{C}$ for $1 \mathrm{~min}$, and $68^{\circ} \mathrm{C}$ for $1 \mathrm{~min}$ ), with a final elongation cycle of $7 \mathrm{~min}$ at $68^{\circ} \mathrm{C}$. The $521 \mathrm{bp}$ fragment (chs sequence plus enzyme sites) was cloned into the pGEMT-Easy vector (Promega Corp.) and sequenced by using universal M13 and T7 primers on an automatic sequencer (ABI Prism1 3700). The chs gene fragment was excised from pGEMT-Easy and inserted in sense (with $\mathrm{Xba \textrm {I }}$ and $K p n \mathrm{I}$ ) and antisense (with $S a c \mathrm{I}$ and $A p a \mathrm{I}$ ) orientations into the vector pSIU (Tinoco et al., 2010) to generate the plasmid pSIUSynchit2. The interfering cassette was removed with EcoRI and HindIII from pSIUSynchit2 and cloned into the vector pCAMBIA1301 (CAMBIA Company; GenBank accession number AF234297.1), generating pCAMBIASynchit2, which was used to transfect Agrobacterium tumefaciens LBA4404 by electroporation. The plasmid pCAMBIASynchit2 was used for tobacco transformation (Nicotiana tabacum 'Xanthi') as previously described by Horsch et al. (1985). The cassette containing the chs sequence hairpin will be referred to as $\Delta c h s$ (Fig. 1a).

\section{Screening of transgenic plants by PCR}

DNA was isolated from leaf disks according to Edwards et al. (1991) and PCR was carried out according to Bonfim et al. (2007). The primer pair ChirnaiF/ChirnaiR within the $\Delta c h s$ cassette was used to amplify a 521 bp sequence.

\section{Progeny analysis}

Seeds of the first generation $\left(\mathrm{T}_{1}\right)$ of self-pollinated plants were germinated and analysed for the presence of the $\Delta c h s$ as

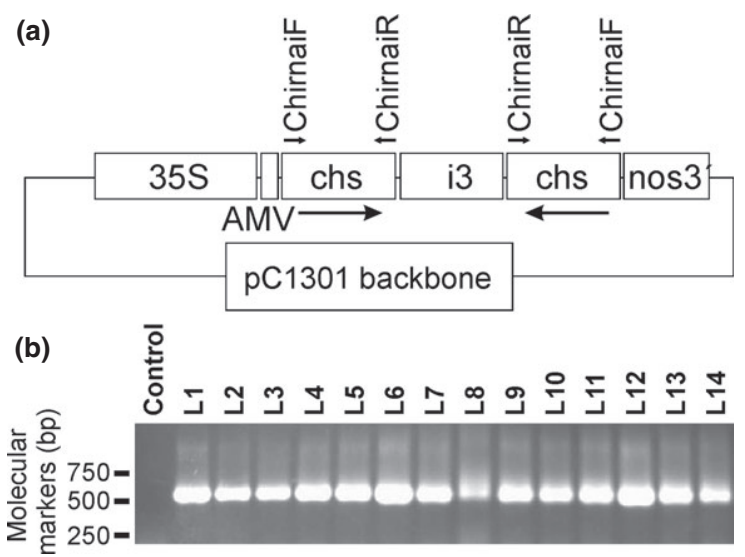

Figure 1 (a) Diagram representing the construct for expressing dsRNA in transgenic tobacco within the PCAMBIASynchit2 plasmid. The intron-hairpin interfering cassette $(\Delta c h s)$ is under the control of the RNA35S promoter of Cauliflower mosaic virus (35S) and the enhancer sequence from Alfalfa mosaic virus (AMV). The $494 \mathrm{bp}$ fragment of the chitin synthase gene coding sequence from Fusarium verticillioides (chs) was directionally cloned in order to generate sense and antisense arms flanking the malate synthase gene intron 3 from Arabidopsis thaliana (i3). The cassette was cloned into the pCAMBIA1301 vector (pC1301), generating PCAMBIASynchit2, which was used to transform tobacco. (b) PCR analysis of transformed lines ( $L 1$ to $L 14$ ) for detection of the chs sequence (using the primer pair ChirnaiF/ChirnaiR). Control is a non-transgenic plant. 
described above and also for GUS gene expression using the histochemical assay according to Jefferson et al. (1987). Chi-square analyses, using the correction factor of Yates (Steel \& Torrie, 1980), were performed to determine whether or not the observed segregation ratio was consistent with a Mendelian ratio $(3: 1$ or $15: 1)$, with a $95 \%$ level of confidence.

\section{Plant inoculation with $S$. sclerotiorum and symptom evaluation}

The detached leaf assay was carried out according to Cunha et al. (2010) using plants from the $\mathrm{T}_{1}$ generation. One or two mycelial agar plugs were applied to the surface of third or fourth fully expanded leaves. Non-transgenic plants and plants transformed with the vector pCAMBIA1301 (without the $\Delta$ chs cassette) were used as controls. Sclerotia were collected from an infected bean field located in Goiás (Brazil) and cultured on potato dextrose agar medium at room temperature to produce mycelia. Leaves were photographed at 48 and $72 \mathrm{~h}$ after fungus inoculation, and images were used to measure the infected area using QUANT v. 1.0.1 software (Vale et al., 2003). The means of the lesion areas were grouped by the Scott \& Knott (1974) test, at $5 \%$ probability (using $\mathrm{R}$ v. 3.1.2; www.R-project.org/). Experiments were repeated twice with four repetitions.

\section{Northern blot analysis of siRNA}

Total RNA was isolated from tobacco leaves ( $\mathrm{T}_{2}$ generation) according to Aragão et al. (2013). Northern blot analysis of siRNA was carried out according to Tinoco et al. (2010). Hybridization was carried out with a DNA probe, corresponding to the PCR fragment amplified using the primer pair ChirnaiF/ChirnaiR, labelled with $\left[\alpha^{32} \mathrm{P}\right]$ dCTP using a random primer DNA labelling kit (Amersham Pharmacia Biotech), according to the manufacturer's instructions. Three oligomers $(18,24$ and 44 nucleotides) were used as molecular size markers. The bands were visualized with a fluorescent image analyser (FLA-3000; Fujifilm).

\section{Quantitative real-time PCR}

The transcription levels of the endogenous Sschs gene in S. sclerotiorum mycelia interacting with transgenic leaves $\left(\mathrm{T}_{2}\right.$ generation) were quantified by quantitative reverse transcription (RT)PCR. Leaves were inoculated with a mycelial disc as previously described. Ninety-six hours after inoculation, the growing mycelia were removed and total RNA was isolated by extraction with Trizol (Invitrogen), as recommended by the manufacturer. The remaining genomic DNA was eliminated by DNase digestion of the RNA samples. Total RNA $(2 \mu \mathrm{g})$ was used to produce cDNA using the reverse transcriptase Superscript III (Promega), according to the protocol suggested by the manufacturer. PCR was performed in an Applied Biosystems 7300 real-time PCR system using SYBR Green (Stratagene), according to the manufacturer's instructions. The amplification programme was $94^{\circ} \mathrm{C}$ for $15 \mathrm{~s}, 58^{\circ} \mathrm{C}$ for $15 \mathrm{~s}$ and $72^{\circ} \mathrm{C}$ for $15 \mathrm{~s}$. The primers for the endogenous Sschs (5'-TCGTATCTGGGTCGCTATCA-3' and 5'-TGCGTACATC

TGGACGTTTC-3'; product size 95 bp; XM001584969.1) and Ss $\alpha$-tubulin (5'-GTCGGTGAAGGTATGGAAGAAG-3' and $5^{\prime}$ CCTCTTCAGCCTCAAAGCTATC-3'; product size $109 \mathrm{bp}$; XM001597572.1) genes were designed using the PrimerQuest tool (IDT Integrated DNA Technologies, Inc.). Products from the PCR reaction were separated by agarose gel electrophoresis and sequenced to confirm the identity of the products. The relative Sschs transcription levels in different RNA samples were normalized with respect to the internal standard Ss $\alpha$-tubulin gene. Triplicate quantitative assays were performed on each

Table 1 Segregation analyses and disease progress of transgenic tobacco lines and controls after inoculation with a Sclerotinia sclerotiorum mycelial agar plug

\begin{tabular}{|c|c|c|c|c|c|c|c|}
\hline \multirow[b]{2}{*}{ Line } & \multicolumn{2}{|c|}{ Lesion area $\left(\mathrm{cm}^{2}\right)^{a}$} & \multicolumn{2}{|c|}{$\mathrm{T}_{1}$ generation $^{\mathrm{b}}$} & \multirow{2}{*}{$\begin{array}{l}\text { Segregation } \\
\text { ratio tested }\end{array}$} & \multirow[b]{2}{*}{$\chi^{2}$} & \multirow[b]{2}{*}{$P^{c}$} \\
\hline & $48 \mathrm{~h}$ & $72 \mathrm{~h}$ & Positive & Negative & & & \\
\hline L13 & $6.35 \pm 3.12 a$ & $20.00 \pm 5.20 a$ & 13 & 7 & $3: 1$ & 0.87 & 0.30 \\
\hline L8 & $5 \cdot 15 \pm 1 \cdot 41 \mathrm{a}$ & $19.13 \pm 4.03 a$ & 18 & 2 & $15: 1$ & 0.13 & 0.49 \\
\hline L12 & $7.19 \pm 3.01 \mathrm{a}$ & $19.04 \pm 5.03 a$ & 18 & 2 & $15: 1$ & 0.13 & 0.49 \\
\hline L9 & $5.31 \pm 2.16 a$ & $15.99 \pm 2.66 a$ & 16 & 4 & $3: 1$ & 0.47 & 0.61 \\
\hline L11 & $4.52 \pm 0.34 a$ & $14.13 \pm 1.24 a$ & 13 & 7 & $3: 1$ & 0.87 & 0.30 \\
\hline L10 & $3.92 \pm 0.35 a$ & $13.32 \pm 2.17 a$ & 14 & 6 & $3: 1$ & 0.20 & 0.61 \\
\hline L14 & $3.67 \pm 0.32 a$ & $12.71 \pm 2.09 a$ & 18 & 2 & $15: 1$ & 0.13 & 0.49 \\
\hline L2 & $2.88 \pm 0.86 a$ & $11.95 \pm 1.08 \mathrm{a}$ & 6 & 14 & $3: 1$ & $20 \cdot 47$ & 0.00 \\
\hline L1 & $2.65 \pm 0.07 \mathrm{a}$ & $11.20 \pm 0.12 a$ & 4 & 16 & $3: 1$ & $30 \cdot 87$ & 0.00 \\
\hline L4 & $2.22 \pm 0.16 a$ & $7.45 \pm 1.84 b$ & 6 & 14 & $3: 1$ & $20 \cdot 47$ & 0.00 \\
\hline L5 & $1.64 \pm 0.85 a$ & $3.49 \pm 1.55 b$ & 18 & 2 & $15: 1$ & 0.13 & 0.49 \\
\hline L6 & $1.10 \pm 0.12 a$ & $2.76 \pm 0.21 b$ & 16 & 4 & $3: 1$ & 0.47 & 0.61 \\
\hline L3 & $1.02 \pm 0.07 a$ & $2.65 \pm 0.37 b$ & 3 & 17 & $3: 1$ & 36.87 & 0.00 \\
\hline L7 & $1.39 \pm 0.59 a$ & $2.23 \pm 0.51 b$ & 18 & 2 & $15: 1$ & 0.13 & 0.49 \\
\hline $82 C^{d}$ & $4.02 \pm 1.34 \mathrm{a}$ & $14.47 \pm 1.87 \mathrm{a}$ & & & & & \\
\hline Control $^{e}$ & $5 \cdot 10 \pm 2.37 \mathrm{a}$ & $16.76 \pm 2.83 a$ & & & & & \\
\hline
\end{tabular}

aMeans followed by identical letters, in the columns, do not differ by the Scott-Knott test, at $5 \%$ probability. $n=4$.

${ }^{\mathrm{b}}$ Data are based on PCR analyses for detection of the $\Delta c h s$ cassette and a GUS histochemical assay.

${ }^{c} P$, probability that observed ratios reflect expected segregation ratio of 3:1 or 15:1.

dPlants transformed with pCAMBIA1301 without the $\Delta$ chs cassette.

eNon-transgenic plants. 

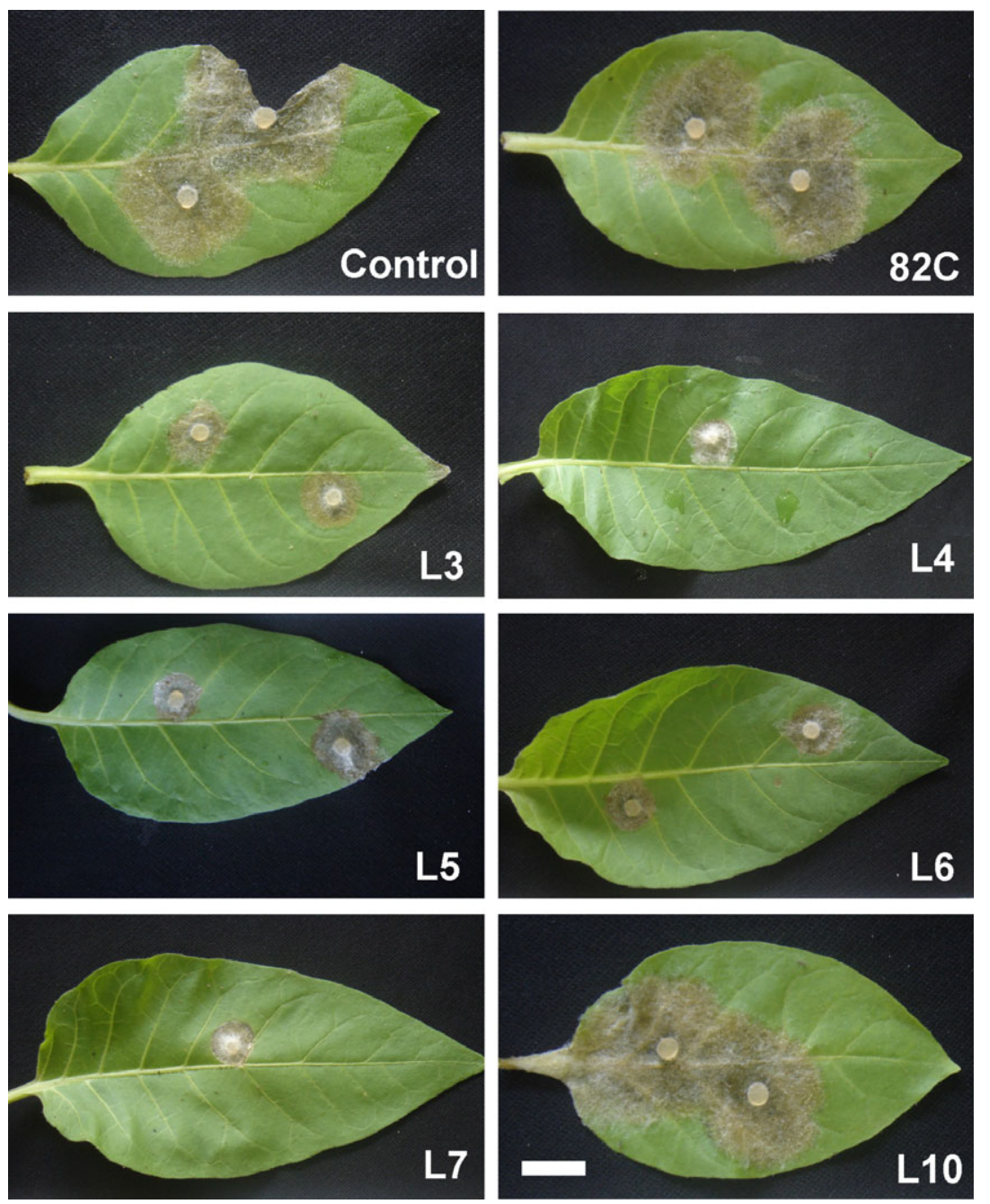

Figure 2 Resistance response of transgenic tobacco plants to Sclerotinia sclerotiorum inoculation. Symptoms observed on detached leaves $72 \mathrm{~h}$ after inoculation of transgenic and non-transgenic (control) lines with 5-mm mycelial agar plugs. The line 82C is transformed with pCAMBIA1301 without the $\Delta$ chs cassette. Bar $=2 \mathrm{~cm}$.
cDNA sample. The relative level of expression was calculated using the Livak method (Livak \& Schmittgen, 2001). Results were compared by one-way ANOVA with Dunnett's post hoc test $(\alpha=0.05)$ to analyse the differences between isolates that interacted with each transgenic plant line event, compared to the control using R v. 3.1.2.

\section{Results}

Tobacco plants were transformed with an interfering intron-hairpin construct (Fig. 1a) to express dsRNA molecules corresponding to the chitin synthase gene. Plants were generated to verify if this construction would trigger RNA silencing of the gene in a necrotrophic fungus, resulting in disease severity reduction or suppression. PCR analyses revealed the presence of the $\Delta$ chs cassette in 14 regenerated lines (Fig. 1b) and these lines were rooted, acclimatized and presented normal phenotypes when compared with non-transgenic plants. All acclimatized transgenic lines ( $\mathrm{T}_{0}$ generation) were allowed to produce seeds and segregation analyses revealed that the transgenes segregated in a Mendelian ratio in 10 lines. Lines L6, L9, L10, L11 and L13 presented a segregation ratio of 3:1 (one locus) and the lines L5, L7, L8, L12 and L14 presented a segregation ratio of 15:1 (two loci). However, the lines L1, L2, L3 and L4 presented a non-Mendelian segregation (Table 1).

Detached leaves of $\Delta c h s$-positive plants from the $T_{1}$ generation were inoculated with $S$. sclerotiorum cultures and lesion area was recorded 48 and $72 \mathrm{~h}$ after inoculation. Results showed that five of the 14 transgenic lines presented a delay in symptom development compared with the non-transgenic lines. The infected area at $72 \mathrm{~h}$ after inoculation ranged from 2.2 to $20.0 \mathrm{~cm}^{2}$ (mean $11.1 \mathrm{~cm}^{2}$ ) in the transgenic lines, while in the control (non-transgenic plants) the infected area ranged from 13.1 to $23 \cdot 1 \mathrm{~cm}^{2}$ (mean $16.8 \mathrm{~cm}^{2}$ ). No differences were observed between the non-transgenic plants and plants transformed with the pCAMBIA1301 vector without the $\Delta c h s$ cassette (Table 1 ).

In the three transgenic lines that had the largest phenotypic alteration compared to the controls, the reduction in disease severity $48 \mathrm{~h}$ after inoculation was $86.7 \%$ (for line L7), 84.2\% (for line L3) and $83.5 \%$ (for line L6). 
However, the Scott-Knott test performed on lesion areas of all plants revealed no statistically significant difference between transgenic lines and the control (wild type) $48 \mathrm{~h}$

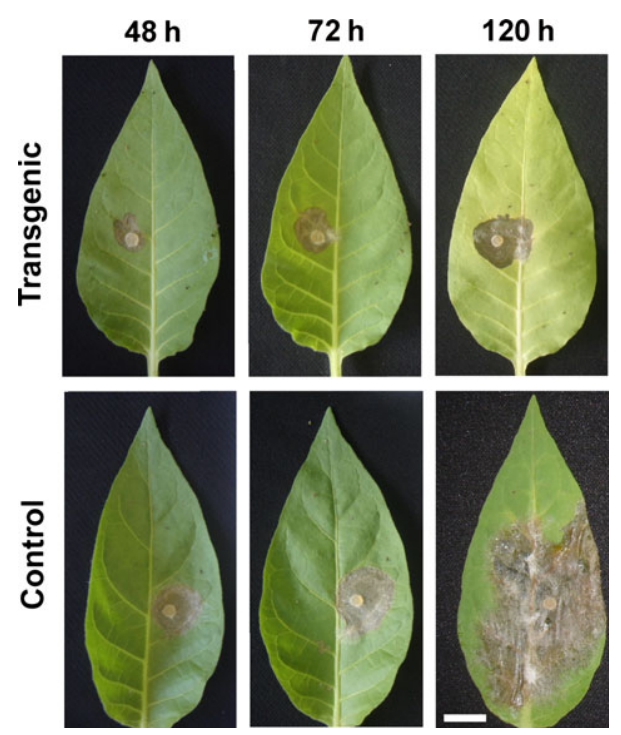

Figure 3 Detail of tobacco transgenic line L5 response to Sclerotinia sclerotiorum mycelium 48, 72 and $120 \mathrm{~h}$ after inoculation, compared to non-transgenic control plants, showing that the lesion area did not present extensive progress over this time (up to $120 \mathrm{~h}$ ) when compared to the control plants. Bar $=2 \mathrm{~cm}$.

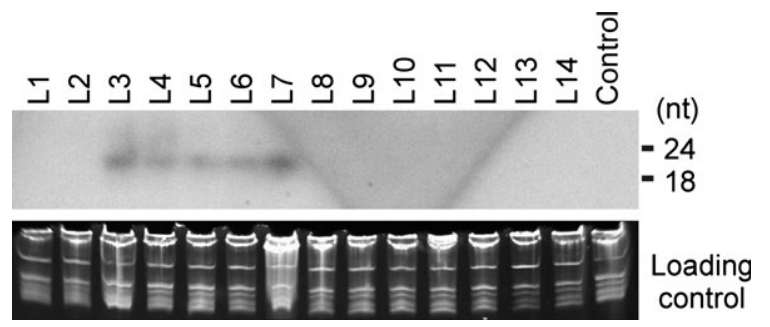

Figure 4 Northern blot analysis to detect the presence of siRNA corresponding to the chs sequence in transgenic and non-transgenic (control) tobacco lines. Ethidium bromide-stained RNA serves as the loading control (below). Molecular size markers are indicated on the right. after inoculation. At 72 h, five lines (L3, L4, L5, L6, L7) revealed a significant reduction in the lesion area compared to the controls and the lesions did not progress extensively up to $120 \mathrm{~h}$ after inoculation (Table 1; Figs 2 $\&$ 3). In contrast, the lesion area continued to grow in the non-transgenic control, reaching the edge of the leaves by $120 \mathrm{~h}$ (Fig. 3). No correlation was observed between the number of transgenic loci and tolerance to S. sclerotiorum (Table 1).

Northern analyses were carried out to detect the siRNA in leaves of transgenic and non-transgenic plants. The analysis showed siRNA detectable bands of the expected size range in the lines L3, L4, L5, L6 and L7. No detectable signal was observed in the other transgenic plants or in the control lines (Fig. 4). These results showed a positive correlation between the presence of detectable siRNA and reduction in disease severity after inoculation with $S$. sclerotiorum.

A quantitative RT-PCR analysis was carried out to verify the cause-effect relationship between silencing of the Sschs gene induced by $S s c h s$-specific siRNA produced by the host and impairment of fungal capacity to colonize host tissues. Sclerotinia sclerotiorum was inoculated on leaves of the best $S$ schs-RNAi expressing lines (L3, L4, L5, L6 and L7) and five lines in which it was not possible to detect the Sschs-RNAi (L8, L9, L10, L13, L44 and non-transgenic) and fungal transcripts were analysed $96 \mathrm{~h}$ after inoculation (Fig. 5). In addition, semiquantitative RT-PCR was carried out to demonstrate the specificity of the primers to distinguish cDNA of the fungus from possible contaminants from the plants. The amplified $95 \mathrm{bp}$ fragment was sequenced and presented $100 \%$ identity with the Sschs gene. No signal was observed in plants not inoculated with the fungus (Fig. 5a). Results showed a reduction in the level of chitin synthase endogenous transcripts in S. sclerotiorum interacting with transgenic leaves. Compared with the control, the reduction ranged from 46.7 to $61.5 \%$ (Fig. 5b). A relationship between the Sschs expression level and lesion area was observed (Fig. 5c). These results suggest that the silencing signal was translocated from transgenic tobacco into fungal cells, partially suppressing expression of the endogenous chitin synthase
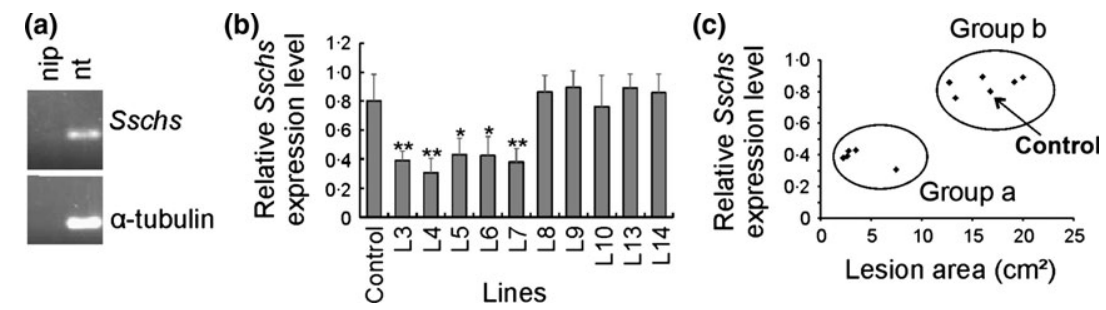

Figure 5 Expression of fungal genes in Sclerotinia sclerotiorum infecting transgenic and non-transgenic (control) tobacco plants. (a) Semiquantitative RT-PCR analysis for detection of Sschs and Ss $\alpha$-tubulin transcripts from mycelium growing in infected non-transgenic plants (nt). A non-inoculated transgenic plant (nip) was also analysed to demonstrate that primers are specific to the fungal genes (b) Relative expression of Sschs $96 \mathrm{~h}$ after inoculation of non-transgenic (Control) and transgenic lines (L3, L4, L5, L6, L7, L8, L9, L10, L13 and L14), determined by quantitative real-time RT-PCR. Data represent means of three replications ( \pm SD). $* P<0.05 ; * * P<0.01, n=9$, related to control. (c) Relation of Sschs expression versus lesion area in transgenic lines L3, L4, L5, L6 and L7 (group a), and L8, L9, L10, L13, L14 and control (non-transgenic line, arrowed) (group b). 
gene and impairing fungal development and leaf infection.

\section{Discussion}

In previous work, the authors reported for the first time that a plant expressing dsRNA could cause the suppression of the corresponding target gene in fungal cells attached to plant tissues (Tinoco et al., 2010). Since then, several reports have demonstrated the biotechnological potential of this approach for the development of fungus-resistant plants (Yin et al., 2011; Nunes \& Dean, 2012; Panwar et al., 2013; Ghag et al., 2014; Govindarajulu et al., 2015). However, fungal species in which HIGS has been effective are biotrophic pathogens. These fungi establish a long-term feeding relationship with the living host cells but do not kill them. On the other hand, it is hypothesized that hemibiotrophic parasites absorb nutrients from host cells in early biotrophic stages and then kill them for nutrient acquisition. For biotrophic fungi, the long period of feeding activity allows the nutrient-absorbing fungal cells to take up dsRNA molecules from their host.

In contrast, necrotrophic pathogens kill host cells faster, often secreting toxins, plant cell wall-degrading enzymes, and proteinases to facilitate host cell death (Zhu et al., 2013). However, recent evidence suggests a strong interaction of necrotrophic pathogens with their host before killing the cells and tissues (Zhu et al., 2013; Kabbage et al., 2015). Sclerotinia sclerotiorum is generally believed to be a typical necrotrophic fungus, being an aggressive pathogen secreting copious amounts of oxalic acid and associated with several cell wall-degrading enzymes that lead to the death of host cells and tissues (Kim et al., 2008). However, recent analysis has suggested Sclerotinia is a hemibiotrophic pathogen, with fungal establishment prior to plant recognition that is more temporally and spatially complex than previously observed (Zhu et al., 2013; Kabbage et al., 2015).

In the present study, the hypothesis was tested that the short interaction period between necrotrophic pathogens and living host tissue would be sufficient to mobilize small RNA molecules from plant to fungal cells, silencing genes in the pathogen. Results have shown that transgenic lines, in which siRNA corresponding to the chs gene was found, presented a significant difference in the lesion area at $72 \mathrm{~h}$. The lesion did not show extensive progress after $120 \mathrm{~h}$, suggesting that fungal cells interacting with living cells at the edge of the lesion were gradually impaired.

As $S$. sclerotiorum is a very aggressive pathogen that develops speedily, there is a delay between acquirement of siRNA molecules and the effect of gene silencing, resulting in delayed symptoms. This corroborates the hypothesis that a hemibiotrophic stage exists in the interaction between $S$. sclerotiorum and the plant, and this allows siRNA molecules to be absorbed by fungal feeding cells and subsequent RNA interference of the Sschs gene.
The chitin synthase gene was chosen because chitin is an important structural component of morphologically distinct structures assembled during various phases of growth and development and is responsible for cell wall rigidity. Chitin biosynthesis is a target for antifungal drugs (Ruiz-Herrera \& San-Blas, 2003) and is an attractive target for obtaining resistant plants via HIGS because chitin is absent in plants, which reduces the probability of any off-target effect of expressing dsRNA corresponding to chs genes. The chs1 gene was inactivated in Neurospora crassa by repeat-induced point mutation (Yarden \& Yanofsky, 1991). Because fungi contain several chitin synthases, mutated $N$. crassa showed a residual chitin synthase activity. Nevertheless, mutants produced slow-growing progeny that formed hyphae with morphologic abnormalities, and this phenotype was correlated with a significant reduction in chitin synthase activity (Yarden \& Yanofsky, 1991). Single mutants with $\Delta c h s 5$ or $\Delta c h s 7$ and the $\Delta c h s 5 / 7$ double mutant of $F$. verticillioides grew poorly and exhibited small, hyperpigmented colonies with very few aerial mycelia compared to the wild type (Larson et al., 2011). In Botrytis cinerea, a model organism for necrotrophic pathogens, the disruption of the $B c c h s 1$ gene reduced chitin synthase activity with a reduction in chitin content of $30 \%$, leading to cell wall weakening and in planta fungal progression (Soulié et al., 2003). Disruption of $B c c h s 3 a$ altered host cell adhesion with reduction in virulence (Soulié et al., 2006; Arbelet et al., 2010). Single deletions of genes coding for distinct chitin synthases indicated that Bcchs 4 is not essential for development and pathogenicity of the fungus, and $B c c h s 7$ is required for pathogenicity in a host-dependent manner. In addition, Bcchs6 disruption generated only heterokaryotic strains, showing that it represents a valuable antifungal target (Morcx et al., 2013).

In the present work, it was demonstrated that endogenous genes from the very aggressive necrotrophic fungus S. sclerotiorum could be silenced by host induction. HIGS of the fungal chitin synthase gene can generate white mould-tolerant plants. As fungi have many chs genes, RNAi expression cassettes that simultaneously silence a group of chitin synthase-coding genes would provide more effective disease control. The progress made in sequencing fungal genomes and understanding fungus-plant interaction will help to identify more appropriate target genes for necrotrophic pathogens. From a biotechnological perspective, these results open new prospects for the development of transgenic plants resistant to necrotrophic fungal pathogens, which are among the most important challenges in plant breeding. Climate change, modification in pathogen populations and fungicide resistance issues have increased the immediacy of this task.

\section{Acknowledgements}

The authors gratefully acknowledge the financial support provided by the Conselho Nacional de Desenvolvimento 
Científico e Tecnológico. C.M.A. was supported by a fellowship from CNPq (Brazil).

\section{References}

Aragão FJL, Nogueira EOPL, Tinoco MLP, Faria JC, 2013. Molecular characterization of the first commercial transgenic common bean immune to the Bean golden mosaic virus. Journal of Biotechnology $166,42-50$.

Arbelet D, Malfatti P, Simon-Côte E et al., 2010. Disruption of the $B c c h s 3 a$ chitin synthase gene in Botrytis cinerea is responsible for altered adhesion and overstimulation of host plant immunity. Molecular Plant-Microbe Interactions 23, 1324-34.

Bolton MD, Thomma BHJ, Nelson BD, 2006. Sclerotinia sclerotiorum (Lib.) de Bary: biology and molecular traits of a cosmopolitan pathogen. Molecular Plant Pathology 7, 1-16.

Bonfim K, Faria JC, Nogueira EOPL, Mendes EA, Aragão FJL, 2007. RNAi-mediated resistance to Bean golden mosaic virus in genetically engineered common bean (Phaseolus vulgaris). Molecular PlantMicrobe Interactions 20, 717-26.

Cunha WG, Tinoco MLP, Pancoti HL, Ribeiro RE, Aragão FJL, 2010. High resistance to Sclerotinia sclerotiorum in transgenic soybean plants transformed to express an oxalate decarboxylase gene. Plant Pathology 59, 654-60.

Dias BBA, Cunha WG, Moraes LS, Vianna GR, Capdeville G, Aragão FJL, 2006. Expression of an oxalate decarboxylase gene from Flammulina sp. in transgenic lettuce (Lactuca sativa) plants and resistance to Sclerotinia sclerotiorum. Plant Pathology 55, 187-93.

Disi JO, Mei J, Wei D, Ding Y, Qian W, 2014. Inheritance of leaf and stem resistance to Sclerotinia sclerotiorum in a cross between Brassica incana and Brassica oleracea var. alboglabra. Journal of Agricultural Science 152, 146-52.

Dong X, Ji R, Guo X et al., 2008. Expressing a gene encoding wheat oxalate oxidase enhances resistance to Sclerotinia sclerotiorum in oilseed rape (Brassica napus). Planta 228, 331-40.

Edwards K, Johnstone C, Thompson C, 1991. A simple and rapid method for the preparation of plant genomic DNA for PCR analysis. Nucleic Acids Research 19, 1349.

Ghag SB, Shekhawat UK, Ganapathi TR, 2014. Host-induced posttranscriptional hairpin RNA-mediated gene silencing of vital fungal genes confers efficient resistance against Fusarium wilt in banana. Plant Biotechnology Journal 12, 541-53.

Govindarajulu M, Epstein L, Wroblewski T, Michelmore RW, 2015. Host-induced gene silencing inhibits the biotrophic pathogen causing downy mildew of lettuce. Plant Biotechnology Journal 13, 875-83.

Horsch RB, Fry JE, Hoffmann NL et al., 1985. A simple and general method for transferring genes into plants. Science 227, 1229-31.

Hu X, Bidney DL, Yalpani N et al., 2003. Overexpression of a gene encoding hydrogen peroxide-generating oxalate oxidase evokes defense responses in sunflower. Plant Physiology 133, 170-81.

Jefferson RA, Kavanagh TA, Bevan MW, 1987. GUS fusions: $\beta$-glucuronidase as a sensitive and versatile gene fusion marker in higher plants. EMBO Journal 6, 3901-7.

Kabbage M, Yarden O, Dickman MB, 2015. Pathogenic attributes of Sclerotinia sclerotiorum: switching from a biotrophic to necrotrophic lifestyle. Plant Science 233, 53-60.

Kesarwani M, Azam M, Natarajan K, Mehta A, Datta A, 2000. Oxalate decarboxylase from Collybia velutipes. Journal of Biological Chemistry $275,7230-8$.

Kim KS, Min J-Y, Dickman MB, 2008. Oxalic acid is an elicitor of plant programmed cell death during Sclerotinia sclerotiorum disease development. Molecular Plant-Microbe Interactions 21, 605-12.

Kim G, LeBlanc ML, Wafula EK, de Pamphilis CW, Westwood JH, 2014. Genomic-scale exchange of mRNA between a parasitic plant and its hosts. Science 345, 808-11.
Knip M, Constantin ME, Thordal-Christensen H, 2014. Trans-kingdom cross-talk: small RNAs on the move. PLoS Genetics 10, e1004602.

Larson TM, Kendra DF, Busman M, Brown DW, 2011. Fusarium verticillioides chitin synthases CHS5 and CHS7 are required for normal growth and pathogenicity. Current Genetics 57, 177-89.

Lilley CJ, Davies LJ, Urwin PE, 2012. RNA interference in plant parasitic nematodes: a summary of the current status. Parasitology 139, 630-40.

Livak KJ, Schmittgen TD, 2001. Analysis of relative gene expression data using realtime quantitative PCR and the $2^{\Delta \Delta C T}$ method. Methods 25, 402-8.

Miklas PN, Grafton KF, 1992. Inheritance of partial resistance to white mold in inbred populations of dry bean. Crop Science 32, 943-8.

Morcx S, Kunz C, Choquer M et al., 2013. Disruption of Bcchs4, $B c c h s 6$ or Bcchs 7 chitin synthase genes in Botrytis cinerea and the essential role of class VI chitin synthase (Bcchs6). Fungal Genetics and Biology 52, 1-8.

Nowara D, Gay A, Lacomme C et al., 2010. HIGS: host-induced gene silencing in the obligate biotrophic fungal pathogen Blumeria graminis. The Plant Cell 22, 3130-41.

Nunes CC, Dean RA, 2012. Host-induced gene silencing: a tool for understanding fungal host interaction and for developing novel disease control strategies. Molecular Plant Pathology 13, 519-29.

Panwar V, McCallum B, Bakkeren G, 2013. Host-induced gene silencing of wheat leaf rust fungus Puccinia triticina pathogenicity genes mediated by the Barley stripe mosaic virus. Plant Molecular Biology 81, 595-608.

Ruiz-Herrera J, San-Blas G, 2003. Chitin synthesis as a target for antifungal drugs. Current Drug Targets - Infectious Disorders 3, 77 91.

Schwartz HF, Singh SP, 2013. Breeding common bean for resistance to white mold: a review. Crop Science 53, 1832-44.

Schwartz HF, Steadman JR, 1989. White mold. In: Schwartz HF, PastorCorrales MA, eds. Bean Production Problems in the Tropics, 2nd edn. Cali, Colombia: CIAT, 211-30.

Scott AJ, Knott M, 1974. Cluster analysis method for grouping means in the analysis of variance. Biometrics 30, 507-12.

Soulié MC, Piffeteau A, Choquer M, Boccara M, Vidal-Cros A, 2003. Disruption of Botrytis cinerea class I chitin synthase gene Bcchs 1 results in cell wall weakening and reduced virulence. Fungal Genetics and Biology 40, 38-46.

Soulié MC, Périno C, Piffeteau A et al., 2006. Botrytis cinerea virulence is drastically reduced after disruption of chitin synthase class III gene (Bcchs3a). Cellular Microbiology 8, 1310-21.

Steel RGD, Torrie JH, 1980. Principles and Procedures of Statistics. New York, NY, USA: McGraw-Hill.

Tinoco MLP, Dias BBA, Dall'Astta RC, Pamphile JA, Aragão FJL, 2010. In vivo trans-specific gene silencing in fungal cells by in planta expression of a double-strand RNA. BMC Biology 8, 27.

Vale FXR, Filho EIF, Liberato JR, 2003. QUANT. A software for plant disease severity assessment. In: Proceedings of the 8th International Congress of Plant Pathology. Vol. 8. Sydney, Australia: Horticulture Australia, 105.

Yarden O, Yanofsky C, 1991. Chitin synthase 1 plays a major role in cell wall biogenesis in Neurospora crassa. Genes \& Development 5 , 2420-30.

Yin C, Jurgenson JE, Hulbert SH, 2011. Development of a host-induced RNAi system in the wheat stripe rust fungus Puccinia striiformis f. sp. tritici. Molecular Plant-Microbe Interactions 24, 554-61.

Zhang H, Li HC, Miao XX, 2013. Feasibility, limitation and possible solutions of RNAi-based technology for insect pest control. Insect Science 20, 15-30.

Zhu W, Wei W, Yanping F et al., 2013. A secretory protein of necrotrophic fungus Sclerotinia sclerotiorum that suppresses host resistance. PLoS ONE 8, e53901. 